\title{
Yeşil Ekonominin İstihdam Üzerindeki Yansımaları ve Yeşil İşler: Cinsiyet Temelli Bir Modelleme ile İngiliz İşgücü Anketinden Bulgular*
}

\author{
The Reflections of Green Economy on Employment, and the Green Jobs: Findings \\ from the British Labour Force Survey through a Gender-based Modelling
}

\author{
Ayhan Görmüş ${ }^{1}$ (D)
}

\section{Öz}

İlim değişikliği, çevre kirliliği, biyolojik çeşitliliğin kaybedilmesi ve doğal kaynakların hızla tükenmesine bağlı doğa olaylarındaki artş̧lar, genel ekonomiyi ve sürdürülebilir kalkınmayı giderek olumsuz yönde etkilemektedir. Buna karşılık, yeşil ekonomiye geçişin iklim değişikliğinin çevre ve genel ekonomi üzerindeki olumsuz etkilerini hafifleteceği ya da tersine çevireceği ileri sürülmektedir. Bu açıdan, bu çalışma yeşil ekonomiye geçişin istihdam üzerindeki olası yansımaları ve yeşil iş kavramını açıklamaya yönelik bir literatür incelemesi sunmayı ve temel olarak İngiltere'deki yeşil işleri analiz etmeyi amaçlamaktadır. Bu araştırmanın yöntemi, 2014 yılı İngiliz İşgücü Anketi mikro verilerine iki yönlü (binary) lojistik regresyon modelleme analiz tekniğini uygulayarak, demografik profil ve istihdam durumu değişkenlerinin yeşil işlerle ilişkisindeki cinsiyet farklılıklarının araştırılmasına dayanmaktadır. Araştırma sonuçları orijinal olarak, İngiltere'deki yeşil işler ile demografik profil ve istihdam durumu değişkenleri arasında değişen derecelerde anlamlı ilişkilerin olduğunu ve yeşil işlerin erkekler lehine istihdamda bir cinsiyet eşitsizliği yaratth̆ını bulmuştur.

\section{Anahtar Kelimeler}

Yeşil ekonomi • Yeşil iş • Yeşil yakalı • İstihdam • İngiliz İşgücü Anketi

\begin{abstract}
Increases in natural events depending on climate change, environmental pollution, the loss of bio-diversity and the rapid extinction of natural resources undermine gradually the general economy and sustainable economic development. As the response this, it is suggested that the transition towards a green economy will reverse or mitigate the negative effects of climate change on the environment and the general economy.
\end{abstract}

* Bu çalışma, 2219-Yurt Dışı Doktora Sonrası Araştırma Burs Programı kapsamında TÜBITAK BiDEB tarafindan desteklenmiştir.

* Bu çalışmanın literatür bölümü, 20.10.2016 tarihinde "Ekonomik Yeşillenmenin İstihdama Yansımaları ve Yeşil İşler" başlığı altında İstanbul Üniversitesi İktisat Fakültesi 65. Sosyal Siyaset Konferanslarında sözlü olarak sunulmuştur.

1 Sorumlu Yazar: Ayhan Görmüş (Doç. Dr.), Tekirdağ Namık Kemal Üniversitesi, İktisadi ve İdari Bilimler Fakültesi, Çalışma Ekonomisi ve Endüstri İlişkileri Bölümü, Tekirdağ, Türkiye. Eposta: agormus@nku.edu.tr ORCID: 0000-0002-6175-5381

Attf: Gormus, A. (2019). Yeşil ekonominin istihdam üzerindeki yansımaları ve yeşil işler: Cinsiyet temelli bir modelleme ile Ingiliz işgücü anketinden bulgular. Sosyal Siyaset Konferansları Dergisi, 76, 29-66. https://doi.org/10.26650/jspc.2019.76.0001 
In this sense, this paper aims to present a literature review to explain the possible reflects of the transition towards a green economy on employment and the green jobs concept, and to examine the green jobs in the United Kingdom. Methods of the study depend on investigating gender differences in the association between the green jobs and demographic and work-status variables, by applying binary logistic regression modelling analysis technique to micro data set from the 2014 British Labour Force Survey. The research results originally found that there were significant relationships between the green jobs and demographic and work-status variables in varying degrees and the green jobs created gender inequality in employment in favour of the male.

\section{Keywords}

Green economy • Green job • Green collar • Employment • British Labour Force Survey 


\section{Extended Summary}

General economy and climate policy issues, two major challenges which the world has faced today, as well as the relationship between both main challenges, have become one of the most debated issues academically and institutionally. The first challenge is to reverse the danger in climate change and prevent deterioration in the progression of natural resources which jeopardise the living standards of the current and future generations. The second challenge is to provide economic growth which creates more and better jobs that offer social development for all. In this line, it is suggested that the transition towards a green economy will reverse or mitigate the negative effects of climate change on the environment and the general economy, and the same time it will offer decent jobs which guarantee work rights, sufficient wage and social security for workers in conditions of freedom, equality, security and human dignity.

There is not a full consensus on the definition of the green economy, however, all definitions meet on common grounds. For example, UNEP defines a green economy "as one that results in improved human well-being and social equity, while significantly reducing environmental risks and ecological scarcities". To sum up, the green economy contains low carbon, resource efficient and socially inclusive. Both public and private sectors can invest in the green economic sectors which mitigate carbon emissions and environmental pollutions, improve energy and resource efficiency, and avoid the loss of bio-diversity and eco-system services.

The investments in green economic sectors will create, on the one hand, directly some new jobs in the green sectors, on the other hand, the indirect jobs in the supplier industries which provide intermediate goods and services for the green sectors. Traditionally, the term "green jobs" was used to quote jobs that contribute to sustainable, protection and development of the environment in the areas of bio-diversity and nature conservation, environmental consultancy, waste disposal and pollution control. However, lately, the meaning of the green jobs has been extended by including jobs in the low carbon sectors such as renewable energy, resource and energy-efficient production, low carbon transport fuels, climate change consultancy and carbon finance sectors.

Admittedly, green economic restructuring will influence both the quantity and quality of jobs in the labour market. In this sense, it is expected that 
the transition to a green economy may create a large number of green jobs and make changes in a large part of existing jobs and occupations in the target sectors. Likewise, it is argued that the green sectors will create more quality jobs than traditional sectors, however, the job quality in green sectors seems still unclear because of the instability of green jobs, non-durable of SMEs against economic fluctuations, constantly changing politic targets and regulations, and union busting. In addition, it is expected that the majority of green jobs will create in the fields of construction, manufacturing and engineering where women employment is significantly lower. Therefore, some green sectors will unintentionally exclude women.

This paper aims to present a literature review to explain the possible reflections of the transition towards a green economy on employment and gender inequality and to examine if green jobs lead to gender inequality in the United Kingdom. In this line, methods of the study depend on investigating gender differences in the association between green jobs and demographic and work-status variables, by applying binary logistic regression modelling to micro data set from the 2014 British Labour Force Survey. The original findings of the research can be summed up following as:

Evidence points out that the British green economy exacerbates gender inequality which excludes women in terms of employment. Also, logistic models highlight that as age increases, the possibility of employment in green jobs is higher. On the other hand, green job opportunities in Wales are more than in other countries. Additionally, as education level increases, employment prospect in the green sectors is better. The majority of green jobs in the UK consist of full-time jobs. And green jobs concentrate in the private sector and large-sized workplaces with 500 and more workers. Logistic analyses point out that while the tendency of trade union membership for workers in the green jobs is lower, the coverage rate of the collective agreement is higher. This result shows that British workers in the green sectors mostly prefer to enter the coverage of collective bargaining by solidarity dues rather than trade union membership. Finally, as a reflection of educational outcomes, high-ranked occupations such as managerial and professional professions and occupations requiring highly-skills increase the employment possibilities in green sectors. 


\section{Yeşil Ekonominin İstihdam Üzerindeki Yansımaları ve Yeşil İşler: Cinsiyet Temelli Bir Modelleme ile İngiliz İşü̈cü Anketinden Bulgular}

Son yıllarda, iklim değişikliği ve onun çevre ve ekonomi üzerindeki etkileri, akademik ve kurumsal olarak en tartışılan konulardan biri haline gelmiştir. İklim değişikliğine bağlı sel basmaları, sıcaklık dalgalanmaları ve yağış seviyelerindeki düşüşler gibi doğa olaylarındaki artışların, çevre kirliliği, biyolojik çeşitliliğin kaybedilmesi ve doğal kaynakların giderek tükenmesinin genel ekonomiyi, daha geniş anlamda sürdürülebilir kalkınmayı ve türetilmiş piyasalar olan işgücü piyasalarını olumsuz yönde etkilemesi beklenmektedir (Görmüş, 2016, s.1083). Bu çerçevede tarım, turizm, sigortacılık, ormancılık, balıkçılık, altyapı ve enerji sektörleri iklim değişikliğinin direkt etkilerine karşı yüksek derecede hassas sektörler olarak tanımlanmaktadır (MartinezFernandez vd., 2010, s.8; Görmüş, 2016, s.1083). Bu yüzden, iklim değişikliği tehlikesi karşısında günümüz ve gelecek nesillerin yaşam standartlarının korunabilmesi, karbon emisyonu ve çevre kirliliğini azaltan, enerji ve kaynak etkinliğini artıran, biyo-çeşitlilik ve eko-sistemi koruyan yeni bir ekonomik büyüme modelini gerekli kılmaktadır (ILO, 2013a, s.8-9; ILO ve OECD, 2012, s.2). Aksi takdirde, orta ve uzun dönemli iklim değişikliği projeksiyonlarında, dünya çapında birçok sektörde ekonomik ve sosyal aktivitelerin ciddi şekilde bozulacağı tahmin edilmektedir (Evans-Klock vd., 2009, s.8-9; ILO, 2012, s.2). $\mathrm{Bu}$ açıdan, düşük karbonlu ve kaynak etkin yeşil ekonomiye geçiş, artık bir alternatif değil, bir zorunluluk haline gelmiştir. Bu konunun önemi Birleşmiş Milletler Çevre Programı (UNEP), Ekonomik Kalkınma ve İşbirliği Örgütü (OECD), Dünya Bankası ve Uluslararası Çalışma Örgütü (ILO) gibi kuruluşlar tarafından da sürekli gündemde tutulmaktadır. Bu örgütler arasında yeşil ekonominin tanımı üzerinde tam bir uzlaşı olmamasına rağmen, bütün tanımlar ortak bir zeminde buluşmaktadır. Örneğin UNEP (2011), yeşil ekonomiyi "çevresel riskleri ve ekolojik kıtlıkları önemli ölçüde azaltıllyorken, insan refahının ve sosyal eşitliğin geliştirilmesi” olarak tanımlamaktadır. Diğer taraftan Dünya Bankası'na (2012) göre yeşil ekonomik büyümenin, “doğal kaynakların kullanımında etkin, kirlilik ve çevresel etkileri minimize edecek kadar temiz, fiziki felaketleri önlemede çevresel yönetimin ve doğal sermayenin rolünü ve doğal afetleri hesaba katacak kadar elastik ve aynı zamanda içermeci olması" gerekmektedir (Görmüş, 2016, s.1082-1083). OECD (2011) ise yeşil büyümeyi, "ekonomik büyüme sağlanıyorken, insanın iyiliği ve refahı 
için gereken doğal kaynakların ve çevresel hizmetlerin sürdürülebilirliğinin güvence altına alınması" olarak tanımlamaktadır. Bu açıdan, yeşil ekonomik büyüme yeni teknolojilere, yeni ekipmanlara, yeni binalara ve yeni altyapılara büyük ölçekli yatırımları içermektedir (OECD, 2011, s.9).

$\mathrm{Bu}$ çalışma, yeşil ekonominin istihdam ve istihdamdaki cinsiyet eşitsizliği üzerindeki olası yansımalar ile yeşil iş kavramını açıklamaya yönelik bir literatür incelemesi sunmayı ve temel olarak, dünyanın en büyük endüstriyel kirleticisi olmamasına rağmen, iklim değişikliğinin olumsuz etkilerini önlemede lider ülke olmayı hedefleyen (DEEC, 2009; Görmüş, 2016, s.1082) İngiltere' örneğini analiz etmeyi amaçlamaktadır. Bu çerçevede, yeşil ekonomiye geçiş ve istihdamla ilgili literatüre katkı sağlamak amacıyla hazırlanan bu çalışmanın cevap arayacağı sorular şunlardır: Yeşil işleri diğer işlerden ayıran göstergeler nelerdir? Yeşil ekonomiye geçişin istihdamın niceliği ve niteliği üzerindeki olası etkileri nelerdir? Yeşil işler istihdamda bir cinsiyet eşitsizliği yaratıyor mu? İngiliz işgücü piyasasında demografik ve istihdamla ilgili değişkenler ile yeşil işler arasındaki ilişki, cinsiyetlere göre nasıl farklılaşıyor? Bütün bu sorulara cevap bulabilmek için, öncelikle yeşil ekonominin istihdama yansımaları ve yeşil işlere yönelik daha önce yapılmış çalışmalar ve uluslararası örgütlerin raporları ayrıntılı olarak incelenecektir. Daha sonra, 2014 İngiliz İşgücü Anketi (LFS) mikro verisi kullanılarak, yeşil işler ile demografik ve istihdam durumu (ayrıntılar için yöntem bölümüne bakınız) değişkenleri ilişkisindeki cinsiyetler arası farklılıklar, ki-kare ve iki yönlü (binary) lojistik regresyon modelleme analiz teknikleri ile değerlendirilecektir.

Çalışmanın geri kalan kısımları; yeşil kavramı ve göstergelerinin açıklandığı "Yeşil İş Kavramı ve Göstergeleri", yeşil ekonomiye geçişin istihdam açısından değerlendirildiği "Yeşil Ekonomiye Geçişin İstihdam ve Cinsiyet Eşitsizliği Üzerindeki Yansımaları”, araştırmanın verisi, bağımlıvebağımsızdeğişkenleri ve analiz tekniğinin tanıtıldı̆̆ "Yöntem" ve elde edilen bulguların değerlendirildiği “Araştırma Sonuçları" ile "Sonuç” bölümlerinden oluşmaktadır.

\section{Yeşil İş Kavramı ve Göstergeleri}

Son yıllarda, küresel iklim değişikliğinin önüne geçilmesi için fosil yakıttan bağımsız üretim yapan sektörlerce istihdam edilen işçilerin sayısındaki

1 İngiltere, Galler, İskoçya ve Kuzey İrlanda'nın oluşturduğu Birleşik Krallık’tan çalışma boyunca "İngiltere" olarak bahsedilecektir. 
artış ve çevresel teknolojilerdeki ilerlemelerden dolayı, bazı mavi yakalılar ve beyaz yakalılar "yeşil yakalılar" olarak anılmaya başlanmıştır (Özsoy, 2011, s.21). Aslında, yeşil yakalı terimi sadece çevrenin korunmasına katk1 sağlayan sektörlerdekileri değil, aynı zamanda daha iyi çalışma koşulları sunan işlerde çalışanları kastetmek için kullanılmaktadır. Bu anlamda, ABD merkezli Apollo Alliance yeşil yakalı işleri, çevresel kalitenin artırılmasına ya da korunmasına direkt katkı sağlayan, iyi ücretli ve kariyer yolu olan işler olarak tanımlamaktadır. Bu yönüyle, eğer bir iş, çevresel gelişmeye katkıda bulunuyor, ancak insan onuruna uygun bir ücret ya da yüksek vasıflı işlerde kariyer firsatları sunmuyorsa, bu tip işler yeşil yakalı iş olarak kabul edilmemektedir. Yeşil yakalılar, düşük vasıf gerektiren işlerden yüksek vasıf gerektiren işlere kadar her seviyede istihdam firsatı bulabilmektedir (Gordon ve Jeremy, 2008, s.3; Özsoy, 2011, s.22). Yeşil yakalı işler, yeşil işler ile aynı anlama gelmekle birlikte, literatürde yeşil iş terimi daha yaygın kullanılmaktadır. Bu açıdan, yeşil sektörlerdeki yeşil yakalı işleri ifade etmek için bu çalışma boyunca "yeşil iş" terimi kullanılacaktır.

Geleneksel olarak, yeşil işler biyolojik çeşitlilik, doğa koruma, çevresel danışmanlık, atıkların imhası ve kirlilik kontrolü gibi alanlarda çevrenin sürdürülebilirliğine, korunmasına ve gelişmesine katk1 sağlayan işleri belirtmek için kullanılmıştır. Ancak, yeşil işler ile işgücü piyasasının belirli bir parçası ya da sektöründe yapılan işleri tanımlamaya yönelik, yeşil işlerin çerçevesini tam anlamıyla çizmek hiçte kolay değildir. Bu bağlamda, son dönemde yeşil işlere yenilenebilir enerji, kaynak ve enerji etkin üretim, düşük karbonlu ulaşım yakıtları, iklim değişikliği danışmanlığı ve karbon finansmanı sektörlerindeki düşük karbonlu işler de dahil edilerek, bu kavram genişletilmiştir (Bird ve Lawton, 2009, s.14). UNEP/ILO/ITUC tarafından hazırlanan raporda (2008) yeşil işler "çevre kalitesinin korunmasına veya restore edilmesine sürdürülebilir şekilde katkı sağlayan tarım, üretim, ARGE, yönetim ve hizmet işleri olarak tanımlanmaktadır" (Özsoy, 2016, s.52). Bu tanıma göre yeşil işler, tamamı olmamak koşuluyla, özellikle eko-sistemi ve biyolojik çeşitliliği korumaya yardım eden, yüksek etkinlik stratejileri ile enerji, malzeme ve su tüketimini azaltan, karbonsuz ekonomi ile atık ve kirliliğin tüm biçimlerinden tümüyle kaçınan ya da minimize eden işleri kapsamaktadır (UNEP/ILO/ITUC, 2008, s.3). Başka bir çalışmasında ILO, yeşil iş kavramını ekonomilerin, kuruluşların, işyerlerinin ve işgücü piyasalarının karbondan arınmış ve sürdürülebilir düzgün işler sunan bir 
ekonomiye geçişi olarak özetlemektedir (ILO, 2012, s.1). Eurostat ise, yeşil işleri tanımlamak yerine, çevresel mal ve hizmet sektöründeki istihdamı ölçmeye odaklanmıştır. Eurostat'a göre, çevresel mal ve hizmet sektörü, doğal kaynakların kullanımını ve kirliliği minimize eden veya önleyen teknoloji, mal ve hizmet üreticilerinin heterojen bir kümesidir. Bu yüzden, çevresel aktiviteler, çevresel koruma ve kaynak yönetimi olmak üzere iki temel bölüme ayrılmaktadır. Yalnız burada kullanılan teknolojide, üretilen mal ve hizmetlerin birincil amaçlarının çevresel koruma veya kaynak yönetimi (çevresel amaç) olduğu düşünülmelidir. $\mathrm{Bu}$ nedenle, Eurostat'ın yeşil iş kavramına temel olarak, çevresel amaçlar taşımayan mal ve hizmetler dâhil edilmemektedir (EMCO, 2010, s.3).

İklim değişikliğine adapte olmuş toplumlar ve işletmeler, enerji ve ham madde tüketimini azaltan, sera gazı emisyonunu sınırlandıran, atık ve kirliliği minimize eden, eko-sistem ve biyolojik çeşitliliği restore eden ve koruyan yeşil işler sunmaktadır (ILO, 2013a, s.6). Bununla birlikte, ILO ve UNEP, bu özelliklerinin yanı sıra, yeşil işlerin yeterli ücret, güvenli çalışma koşulları, iş güvencesi ve iyi kariyer firsatlarına sahip ve işçi haklarına sayg1lı düzgün işler olması gerektiğini vurgulamaktadır (Özsoy, 2016, s.52). Ancak, UNEP'in önerdiği düzgün iş koşullarını karşılamak bazı gelişmekte olan ülkeler için hiçte kolay değildir. Bu durum, Upadhyay ve Pahuja'nın (2010) Hindistan üzerine yaptığı çalışmalarında da vurgulanmıştır. Hindistan biyo-yakıt ve biyo-kütle üretimi sektörlerinde birçok iş yaratmasına rağmen, vasıfsı işgücünün istihdam edildiği bu işler, zor çalışma koşulları ve sadece geçimlik ücret sunduğu için ILO ve UNEP'in önerdiği düzgün iş koşullarını karş1layamamıştır (Upadhyay ve Pahuja, 2010, s.19).

Yeşil sektörlerdeki belirtilen nitelikleri taşıyan işler yeşil işler olarak bilinmektedir. Ancak, yeşil işlerin bazıları imalat, kurulum, bakım ve tarım gibi geleneksel sektörlerde yer alırken, diğer bazıları da yenilenebilir enerji (rüzgâr, güneş, jeotermal bio-yakıt vb.) enerji etkin sektörler, yap1 güçlendirme, inşaat ve ulaşım hatları gibi yeni gelişen yeşil sektörlerde yer alabilmektedir. Çevre düzenleme, organik tarım ve yalıtım sektörleri ise, yeşil işlerin yoğun olduğu sektörler olarak bilinmektedir. Bunlara ilaveten, yeşil ekonomideki gelişmeyle birlikte, yeşil işlerin geri dönüşüm endüstrileri, yeni malzemelerin geliştirilmesi ve üretimi, kamu ulaşımı, her türlü çevresel hizmetler (AR-GE, danışmanlık, eğitim, izleme ve 
yönetim vb.) ve atık yönetimi gibi sektörlerin de, bu sektörlerdeki yatırım artışına bağlı olarak, sürekli geliştiği gözlenmektedir (Jacobs, 1991, s.178). Bu sektörlerde istihdam edilen özellikle çevre veya biyolojik sistem mühendisleri, çevre danışmanları, ekolojik mimarlar, güneş ve rüzgar enerjisi mühendisleri, yeşil araç mühendisleri, organik tarımla uğraşanlar, çevre hukukçuları, çevre eğitmenleri, çevre koruma ve ekoteknoloji alanında çalışanlar yeşil ekonomiye bağlı olarak ortaya çıkmış yeni meslekler olarak sayılabilir. Ayrıca, somut olarak güneş panelleri ve tesisatı işlerindeki elektrikçiler ve diğer çalışanlar, enerji etkin yeşil binaların ve rüzgâr enerjili çiftliklerin inşasında çalışan yapı ve yalıtım işçileri, temiz, yenilenebilir ve sürdürülebilir enerji gelişiminin dâhil olduğu diğer işler de yeşil iş kategorisinde yer almaktadır (Baykan, 2009, s.1; Sungur, 2011, s.5). Bununla birlikte, geleneksel mesleklerin birçoğu, yeşil sektörlerdeki işgücü açığını karşılamak için yeşil ekonominin ihtiyaç duyduğu iş-vasıf gereklerine yönelik eğitim ve yeniden eğitimlerle, yeşil işlere dönüştürülebilmektedir. Örneğin, ABD'de bina ve yapı güçlendirme işleri üzerinde çalışan inşaat şirketleri geleneksel inşaat işleri vasıflarının yanı sıra, enerji etkinliği üzerine eğitim almış işgücüne de ihtiyaç duymaktadır. Benzer şekilde, güneş paneli şirketleri hem geleneksel elektrik işleri becerilerine, hem de özel güneş paneli becerilerine sahip elektrik teknisyenleri talep etmektedir (Gordon ve Jeremy, 2008, s.3). Ancak, geleneksel sektörlerdeki bütün işleri çevrenin korunması ve restorasyonu anlamında yeşil iş olarak düşünmenin imkânı yoktur. Örneğin, nükleer enerji sektörü düşük karbonlu endüstrilerden biri olmasına rağmen, bu sektörlerdeki bütün işler yeşil olarak kabul edilemez. Benzer şekilde, otomotiv endüstrisindeki işlerin bazıları, yeni düşük karbonlu ya da hibrit otomobiller geliştirseler bile, bu sektördeki işlerin tümü yeşil iş olarak kabul edilemezler (Bowen, 2012, s.7-8). Çünkü nükleer enerji santrallerinin ve hibrit otomobillerin pillerinin çevre üzerinde bir takım olumsuz etkileri ve risklerinin olduğu bilinmektedir.

Pollin ve arkadaşları (2008) yaptıkları çalışmalarında yapı güçlendirme, kitlesel ulaşım ve demiryolu taşımacılığı, akıllı enerji şebekeleri, rüzgâr ve güneş panelleri üretimi ve ileri biyo-yakıt alanlarından oluşan altı anahtar yeşil altyapı yatırım stratejisi belirlemişlerdir. Tabloda 1'de gösterilen bu altyapı yatırım stratejileri, yeşil ekonomiyi yapılandırılarak, yeni iş aktiviteleri oluşturmaktadır. Buna göre, yeşil ekonomik yapılanma ile oluşturulan bu yeni 
iş aktivitelerinin bir kısmı güneş panelleri kurulumu ve yeni inşaat malzemesi teknolojileri araştırması gibi özel alanlarda, diğer bir kısmı da insanların zaten günümüzde çalıştığ 1 geleneksel istihdam alanlarında olacaktır. Ancak, Pollin ve arkadaşları hizmet ve destek aktiviteleri ile uğraşan muhasebeciler, hukukçular, insan kaynakları yöneticileri, kasiyerler ve perakende satışı gibi işleri, listelerine dâhil etmemişlerdir. Çünkü bu işler onların belirlediği altı yeşil yatırım stratejisine zaten endirekt olarak bağlıdır (Pollin vd., 2008, s.5).

Tablo 1

Yeşil yatırımlar ve yeşil işler

\begin{tabular}{|l|l|}
\hline $\begin{array}{l}\text { Yeşil Ekonomik } \\
\text { Yatırım Stratejileri }\end{array}$ & \multicolumn{1}{|c|}{ Temsil Ettiği İşler } \\
\hline Yapı Güçlendirme & $\begin{array}{l}\text { Elektrikçiler, 1sıtma/hava iklimlendirme kurulumu yapanlar, } \\
\text { marangozlar, inşaat aracı operatörleri, çatı ustaları, yalıtım işleri } \\
\text { yapanlar, endüstriyel kamyon sürücüleri, inşaat yöneticileri. }\end{array}$ \\
\hline $\begin{array}{l}\text { Toplu Taşıma/ } \\
\text { Demiryolu } \\
\text { Taşımacılığı }\end{array}$ & $\begin{array}{l}\text { İnşaat mühendisleri, demir yolu çalışanları, elektrikçiler, kaynakçılar, } \\
\text { metalciler, motor birleştirici, üretim yardımcıları, otobüs sürücüleri, } \\
\text { hareket memurları, lokomotif mühendisleri, demiryolu kondüktörleri. }\end{array}$ \\
\hline Akıllı Ağlar & $\begin{array}{l}\text { Bilgisayar yazllımı mühendisleri, elektrik mühendisleri ve teknisyenleri, } \\
\text { kaynakçılar, makineciler, inşaat işçileri, endüstri mühendisleri, elektrik } \\
\text { hattı kurucuları ve tamircileri. }\end{array}$ \\
\hline Rüzgâr Enerjisi & $\begin{array}{l}\text { Çevre mühendisleri, demir-çelik işçileri, saç işçileri, makineciler, } \\
\text { elektrik donanımcıları, inşaat araç operatörleri, endüstriyel kamyon } \\
\text { sürücüleri, sanayi üretim müdürleri, üretim denetçileri. }\end{array}$ \\
\hline Güneş Enerjisi & $\begin{array}{l}\text { Elektrik mühendisleri, elektrikçiler, endüstriyel makineler mekaniği, } \\
\text { kaynakçılar, metalciler, elektrik donanımcıları, inşaat araç operatörleri, } \\
\text { tesisatçlar, işçiler, inşaat yöneticileri. }\end{array}$ \\
\hline Gelişmiş Biyo-yakıt & $\begin{array}{l}\text { Kimya mühendisleri, kimyagerler, kimya teknisyenleri, karıştırma ve } \\
\text { harmanlama makinesi operatörleri, tarım işçileri, endüstriyel kamyon } \\
\text { sürücüleri, çiftlik ürünü satanlar, tarım ve orman denetçileri, tarım } \\
\text { müfettişleri. }\end{array}$ \\
\hline
\end{tabular}

Kaynak: Pollin vd., 2008, s.6; Özsoy, 2011, s.22.

Pollin ve arkadaşlarının listelediği bu işler, yeşil iş olarak kabul edilseler bile, bir işin ne kadar yeşil olduğunu öğrenmenin birden fazla yolu bulunmaktadır. Mesleki ya da sektörel anlamda temel olarak kullanılacak standartların bulunmaması durumunda, özellikle politika yapıcılar için bir işin ne kadar yeşil olduğunu bütün boyutlarıyla anlamak, hiçte kolay değildir. Bu anlamda Martinez-Fernandez ve arkadaşları, bir işin ne kadarının yeşil olduğunun anlamaya ve yeşil iş aktiviteleri geliştirmede referans olarak kullanılabilecek, Tablo 2'de yer alan, bir takım kriter ve göstergeler kümesi önermişlerdir (Martinez-Fernandez vd., 2010, s.25-26). 
Tablo 2

Yeşil iş göstergeleri

\begin{tabular}{|c|c|}
\hline \multirow{2}{*}{ Endüstri } & $\begin{array}{l}\text { Sektörü: Sektör ya da endüstri firmalarının kategorize edilebildiği faaliyet } \\
\text { alanlarını temsil etmektedir. Yeşil sektörler genellikle yenilenebilir enerji, } \\
\text { inşaat, ulaştırma, geri dönüşüm, yiyecek ve tarım, orman ve turizmi } \\
\text { içermektedir. Bu sektörler yeşil işler üzerindeki çalışma odaklarını, sadece } \\
\text { ürettikleri mal ve hizmetin doğasından değil, aynı zamanda emek yoğun } \\
\text { olmalarından almaktadır. }\end{array}$ \\
\hline & $\begin{array}{l}\text { Ürün/Hizmeti: } \mathrm{Bu} \text { endüstri ve sektörlerin farklılaşmasında işletmelerin } \\
\text { özellikli çıktılarını temsil etmektedir. Bunlar, ürünün içerdiği eko-inovatif } \\
\text { süreçlerden dolayı yeşil olduğu düşünülen özellikli ürün ve hizmetlerdir. } \\
\text { Örneğin, ürün/hizmetin çevre üzerinde insan aktivitesinin negatif etkisini } \\
\text { azaltmayı ya da sınırlamayı (enerji etkin ev alet ve gereçleri) ya da çevreyi } \\
\text { direkt olarak geliştirmeyi amaçlaması (atık geri dönüşüm sistemleri). }\end{array}$ \\
\hline \multirow{3}{*}{ Organizasyon } & $\begin{array}{l}\text { Üretim Metodu: Üretim metodu firmaların üretim süreçlerinde kullandığ } 1 \\
\text { çevre kalite standartlarını temsil etmektedir. Firmalar enerji tüketimine, atık } \\
\text { üretimini azaltmaya, üretim süreçleri için çevreye dost altyapı inşa etmeye } \\
\text { yönelik tedbirler alabilirler. }\end{array}$ \\
\hline & $\begin{array}{l}\text { Yeşil Farkındalı̆̆ı: Organizasyonların yeşil ve çevre sorunlarına farklı } \\
\text { seviyelerde bağlılıkları vardır. Bazı durumlarda, firma yöneticilerinin } \\
\text { çevre sorunlarına derin bir şekilde bağlanması ve çevreyi korumak için } \\
\text { birlikler, ortaklıklar ve toplumsal hareketlerle uğraşması bireyseldir. Yeşil } \\
\text { farkındalık ayrıca organizasyonun kurumsal sosyal sorumluluk düzeyini de } \\
\text { yansıtmaktadır. Bu genellikle organizasyonun tarihi ve altyapısıyla ilgilidir. }\end{array}$ \\
\hline & $\begin{array}{l}\text { Değerler zincirindeki pozisyonu: Yeşil ekonomideki bir iş uygulamas1 } \\
\text { üretilen mal ya da hizmetin değerler zinciri boyunca değişebilir. Enerji etkin } \\
\text { otomobiller üreten şirketteki bir işin yeşil olduğu düşünülebilir, ancak bu } \\
\text { otomobil için direksiyon üreten tedarikçi şirketteki bir iş için de düşünülebilir } \\
\text { mi? }\end{array}$ \\
\hline \multirow{4}{*}{ İş } & $\begin{array}{l}\text { Mesleki profil: Mesleki profil, faaliyet gösterilen sektöre bakılmaksızın işin } \\
\text { amacını ve niteliğini ifade eder. Neredeyse her mesleğin, insan aktivitesinin } \\
\text { çevre üzerindeki zararlı etkilerini azaltmaya direkt ya da endirekt katk1 } \\
\text { sağladığı sürece, yeşil olduğu düşünülebilir. Sonuç olarak, yöneticilerden, satış } \\
\text { işçilerine ve diğer işçilere kadar uzanan mesleklerin tümünün bazı noktalarda } \\
\text { yeşil olduğu düşünülebilir. }\end{array}$ \\
\hline & $\begin{array}{l}\text { Yeşil iş yükü̈: Bazı çalışanlar bazı işlerini yeşil bir alanda, bazıları ise, } \\
\text { geleneksel alanlarda yapabilir. Bu durumda, eğer yapılan iş yeşil iş olarak } \\
\text { düşünülüyorsa, yeşil görevleri belirlemeye adanmış iş yükünün bir kısmının } \\
\text { yeterli şekilde ölçülmesi önemlidir. }\end{array}$ \\
\hline & $\begin{array}{l}\text { Gerekli beceri ve yetenekler: Belirli işler, işçilerin belirli özel yeşil beceri ve } \\
\text { yeteneklere sahip olmasını gerektirmektedir. Bir işin yeşil olup olmadığının } \\
\text { belirlenmesi, bazı durumlarda onu yapmak için gerekli beceri ve yetenek } \\
\text { gerekliliği temelinde yapılabilir. }\end{array}$ \\
\hline & $\begin{array}{l}\text { Düzgün iş: UNEP ve ILO yeşil işlerin yeterli ücret, güvenli çalışma koşulları, } \\
\text { iş güvencesi, makul kariyer fursatları sunan ve çalışan haklarına saygıll düzgün } \\
\text { işler olması gerektiğini her ikisi vurgulamıştır. Bu yüzden, işlerin düzgün } \\
\text { olması, yeşil işlerin önemli bir boyutudur. }\end{array}$ \\
\hline
\end{tabular}

Kaynak: Martinez-Fernandez vd., 2010, s.22-23.

Yukarıdaki tabloda detaylı olarak listelenen bu dokuz göstergenin birçoğu birbirine bağılıdır ve biri diğerinden ayrı tutulamaz. Ancak bir işin yeşil iş olarak kabul edilebilmesi için işlerin karşılaması gereken minimum koşullar, 
mutlaka tanımlanmış olmalıdır. Yeşil işleri belirlemeye yönelik tek bir kriter kullanmak, zaten bir çok soruna yol açacaktır. Bu açıdan, yeşil işleri tanımamak için uygulanacak bu kriter ve göstergeler, yeşil iş tanımlarının yerel koşullar ve politika önerileri ile eşleşmesi için nispeten bir esneklik sağlayabilir ve yeşil ekonomiye geçiş sürecinde kullanışlı olabilir. Böylece bu kriter ve göstergeler politikacıların politik amaçlarla yerel koşulların uyumunu sağlayacak tanımlamalara kolayca ulaşmasını sağlayabilir. Ayrıca işleri yeşilleştirmeye katk1 sağlayan Tablo 2'deki bu kriter ve göstergeler, yerel yeşil ekonomi ve istihdamı geliştirme politikalarının oluşturulmasını, uygulanmasını ve değerlendirilmesini kolaylaştıracaktır. Bu açıdan, işlerin yaratılması, ikamesi ve dönüşümünü değerlendiren politikalara katkı sağlamak için yararlı bir veri seti oluşturmadan ve makul önlemler alınmadan önce, yeşil iş göstergeleri öncelikli bir adımdır (Martinez-Fernandez vd., 2010, s.27).

\section{Yeşil Ekonomiye Geçişin İstihdam ve Cinsiyet Eşitsizliği Üzerindeki Yansimaları}

Çevresel kirlilik, biyo-çeşitlilik kaybı ve çevrenin, doğal kaynakların ve eko-sistemin hızla tahrip edilmesinin sürdürülebilir ekonomik büyüme ve türetilmiş piyasalar olan işgücü piyasaları üzerindeki olumsuz etkileri, eninde sonunda yeşil ekonomiye geçişi kaçınılmaz hale getirecektir. Ancak, yeni yeşil ekonomi politikaları ve düzenlemeleri (karbon vergisi, emisyon üst sınırı ve ticaret planları, emisyon hedefleri), yeni yeşil teknolojiler ve yeşil piyasalar yeşil sektörlerin büyümesini sağliyorken, özellikle karbon yoğun sektörler başta olmak üzere bazı sektörlerde küçülmelere yol açacaktır. Bu açıdan yeşil ekonomiye geçiş, yeşil işlerin sayısını artırmak için önemli fırsatlar sağlıyorken, işgücü piyasasında gerekli önlemler alınmazsa, önemli ölçüde iş kayıplarına da yol açabileceği akılda tutulmalıdır. Bu yüzden, yeşil ekonomik yapılanmanın işgücü piyasası üzerindeki negatif sonuçlarını azaltmak, yeşil ekonomik büyüme için muhtemel firsatları maksimize etmek ve genel ekonomide daha fazla ve daha iyi işler yaratmak için işletme, toplum ve ulusal seviyesinde pro-aktif bir yaklaşım geliştirilmelidir (Strietska-Ilina, 2011, s.56).

Yeşil ekonomiye geçiş, diğer sektörlerden farklı olarak, daha iyi çalışma koşulları geliştirerek ve daha yüksek iş güvenliği, sağlık ve ücret sunarak, yüksek nitelikli iş gibi önemli bir iddiayı gündeme getirmektedir. Tarım, atık 
yönetimi, geri dönüşüm ve inşaat endüstrileri, gerekli ilerlemeleri sağlamak için farklı nedenler ve opsiyonlar gerektirse bile, işin niteliği anlamında önemli fırsatlar sunabilir (ILO, 2013b, s.34-35). Fakat yeşil ekonomik büyüme, her durumda istihdamın niceliğini ve niteliğini artırmayabilir. Temiz olmasının yanı sıra enerji ve kaynak etkin bir ekonomiye geçiş, meslek profillerinde, vasıf gerekliliklerinde ve işgücü piyasası düzenlemelerinde bazı değişiklikleri gerektirecektir. Bu yüzden, işgücü piyasası kurumları ve aktörleri istihdamdaki artış ve azalışlardan kaynaklanan dalgalanmalara daima hazır olmalıdırlar. Örneğin, yeşil ekonomiye geçişin kömür madenciliği gibi fosil yakıt sektöründe bir azalmaya yol açması kuvvetle muhtemeldir. Bu durum, fosil yakıt sektörlerinin işletildiği bölgelerdeki hem işveren, hem de işçileri etkileyecektir. Dahası, daha temiz enerji kaynaklarına geçiş, en azından belirli bir süre için, enerji maliyetlerinde bir miktar artışa yol açacaktır. İşte bu enerji maliyetlerindeki artış, bazı sektörler üzerinde istihdamı düşüren bir etki yaratabilir. Diğer taraftan, yeşil ekonomik büyüme istihdamın niceliğinde ve niteliğinde bir artış da sağlayabilir. Binalarda, ulaşımda ve endüstrideki enerji etkin yatırımlar, aynı zamanda enerji maliyetlerini düşürebilir. Bunun yanı sıra, yeşil ekonomiye dayalı tarımda, atık yönetiminde ve geri dönüşüm sektörlerindeki işlerin genişlemesi çalışma koşullarını da ilerletebilir. Çevre, istihdam ve sosyal politika, çevre vergileri ve yeşil işler üzerinden alınan gelir vergisi yükünün hafifletilmesine kadar yapılan reformlarla karşılıklı olarak desteklenebilir. Piyasa ve bilgiye dayanan araçlar, düzenleyici araçlar ve gönüllü inisiyatifler gibi politika paketleri, daha önce var olan etkinsizlikleri çözerek, bütün ekonomide hem çevresel iyileşmeyi, hem de ekonomik büyümeyi tetikleyebilir. Özellikle çevresel vergi reformları kazan-kazan politik yaklaşımı için önemli bir örnek olabilir. Karbon emisyon vergileri ve çevresel zarar vergilerinin diğer türleri, istihdamın teşvik edilmesinde kullanılabilen (emek üzerindeki vergi yükü azaltılarak) yeni kamu gelirleri yaratarak ya da yeni enerji etkin teknolojiler geliştirerek veya özellikle gelişen ülkeler için daha uygun olan bir yaklaşımı özendirerek, çevresel gelişme için bir teşvik sağlanabilir (ILO ve OECD, 2012, s.2-3). Bu bağlamda, karbon emisyon vergisinden elde edilen gelirlerin kullanımı açıdan, ABD'deki uygulama oldukça çarpıcı bir örnektir. ABD'de karbon emisyon kontrolü için karbondioksitin her bir metrik tonu için $15 \$$ bir vergi kesintisi yapılmaktadır. Bu vergi "yeşil istihdam vergisi” olarak da bilinmektedir. Bu vergiden elde edilen gelir, her bir işçinin kazancının ilk 
3.660\$'lı kısmı üzerinden işçi ve işveren bordro vergilerine bir geri iade sağlayarak, bordro vergilerinin düşürülmesinde kullanılmaktadır. Ancak, kapsam içindeki bir işçinin geri iade miktarı 560\$'1 geçememektedir. Yeşil istihdam vergi reformu düşük ücretli işçiler için de birçok yardımı beraberinde getirmektedir. Y1llı 5.000\$ kazanan bir işçinin bordo vergisinin yaklaşık 3/4'ü bu vergilerden elde edilen gelirlerle geri iade edilebilmektedir (Metcalf, 2007, s.1-4).

Yeşil ekonomik yapılanmanın işgücü piyasasında işlerin niceliğini ve niteliğini etkilemesi, endüstriden endüstriye farklılık göstermekle birlikte, beklenmektedir. Bu farkl1lıklar sektörlere ve sendikalaşmaya göre değişkenlik gösteren enerji ve işgücü kullanımındaki değişkenliklerden kaynaklanmaktadır. Örneğin, bir sektördeki enerji ve emek yoğunluğu arttıkça, iklim değişikliğinin istihdam üzerindeki etkileri bir o kadar olumsuz bir biçimde yaşanacaktır. Benzer şekilde, sendikasız işyerleri işin niteliği anlamında daha fazla zorluklarla karşılaşacaktır (ILO, 2012). Diğer taraftan, yeşil endüstrilerin istihdam üzerindeki yansıması sektöre, bölgeye, işlerin tipine, vasıf seviyesine ve mesleki yapıya göre değişkenlik gösterebilir. Eğer işyerleri, özellikle de büyük ölçekliler, desteklenmezse, yeşil ekonomik yapılanma düzenlemelerinden dolayı kapanabilirler ve bu durum işlerin niceliği üzerinde negatif bir etki oluşturabilir. Benzer şekilde, bu etkiler bölgesel koşullara, mevcut işlerin alternatiflerine, işgücü hareketliliğine ve endüstri ilişkileri aktörleri arasındaki işbirliğine göre farklılaşabilir. Ayrıca, ekonomik ve finansal kriz yeşil ekonominin istihdam üzerindeki yansımalarını olumsuz olarak değiştirebilir. Hedef sektörlerdeki istihdam modelleri sübvansiyonlar, vergi teşvikleri, tarife garantileri ve kamusal destek önlemlerindeki azalmalardan etkilenebilmektedir (Gaušas vd., 2012, s.21). Bütün bunlar gösteriyor ki, yeşil ekonominin işlerin niceliği ve niteliği üzerindeki yansımaları ayrı ayrı tartışmaya değer konulardır. Bu yüzden bu bölümde, yeşil ekonomiye geçişin istihdamın niceliği ve niteliğinin yanı sıra, istihdamda cinsiyet eşitsizliği üzerindeki olası yansımaları tartışılacaktır.

\section{İstihdamın Niceliği Üzerindeki Olası Yansımaları}

İstihdamın yanı sıra, bütün bir ekonomideki endüstriler ve piyasalar teknolojik ilerlemelerle sürekli dönüşmektedir. Schumpeter (1942) piyasa 
ekonomilerindeki bu olağan dönüşüm sürecini "yaratıcı yıkım” olarak adlandırmaktadır. Eski endüstrilerin yok olmasına ve yeni endüstrilerin ortaya çıkmasına yol açan bu değişim sürecinde ortaya çıkan yeni işlerle vasıfları eşleşen bazı çalışanlar, yeni iş firsatları yakalayabiliyorken, nispi olarak daha düşük vasfa sahip diğer çalışanlar ise, mevcut işlerini kaybedebilirler. $\mathrm{Bu}$ durum reel ekonomide konjonktürel dalgalanmalardan ziyade, yapısal değişikliklerden kaynaklanan "yapısal işsizlik" olarak tanımlanmaktadır (Strietska-Ilina vd., 2011, s.55). Bunun yanı sıra, yeşil ekonomiye geçiş sürecinde, işletmeler ve sektörler arasında ve içinde istihdamda kaymaların yaşanması da oldukça muhtemeldir. Bu geçiş, bütün ekonomide yapısal bir değişime neden olacağı için çevre etkin aktivitelerden uzaklaşılarak, yeşil teknolojilerin geliştirilmesi ve tüm ekonomide uygulanması ile üretilen ve tüketilen mal ve hizmet karmasının değişmesi, işgücü piyasalarını yeniden şekillendirecektir. Bunun nedeni, yeşil ekonomiye geçişin bütün bir ekonomide yapısal bir değişimi tetikleyecek olmasındandır. Bütün bu değişim sürecinin istihdamın niceliği üzerindeki etkileri aşağıdaki gibi beklenmektedir (ILO ve OECD, 2012, s.3);

- Düşüşe geçen sektör ve piyasalarda iş kayıplarının, yeşil ekonomiden kaynaklanan iş artışları ile dengelendiği net etkiler,

- Düşüşe geçen firma ve sektörlerden, gelişen firma ve sektörlere doğru bir işgücü hareketliliği,

- Ne iş kayıplarının, ne de artışlarının olduğu, fakat yeşil ekonominin gereklerini karşılamaya adapte olmuş işlerin geçişi.

Yeşil ekonomik yatırımlar direkt, endirekt ve uyarılmış istihdam etkileri yoluyla yeni istihdam yaratma kanallarını artırabilir. Bir taraftan, örneğin yeşil ekonomik yapılanma, ekonomiyi daha enerji etkin hale getirmek için yapıları güçlendirerek ve rüzgar türbinleri (dizayn, inşa, bakım ve işletim) kurarak, direkt olarak bir takım yeni işler yaratabilir. İşte bu yeşil sektörlerde yaratılan işler, "direkt istihdam etkisi" olarak adlandırılmaktadır. Diğer taraftan, örneğin yapı güçlendirmeleri veya rüzgâr türbinleri için ağaç, çelik ve ulaştırma işleri gibi ara mal ve hizmet üreten tedarik endüstrileri tarafından da başka işler yaratılabilir. İşte tedarik zinciri içerisinde alt sektörlerce yaratılan bu işler "endirekt istihdam etkisi" olarak tanımlanmaktadır. Buna ilave olarak, yeşil ekonomik yapılanma 
bütün ekonomideki diğer üretimler üzerinde de istihdam atışı sağlayabilir. Çünkü yeşil sektörlerde istihdam edilen işçiler direkt ve endirekt malların üretiminden kazandıkları gelirlerini bütün ekonomi içinde harcarlar. Yeşil sektörlerde istihdam arttıkça, yeşil olmayan sektörler üzerindeki uyarılmış istihdam etkisi ile daha fazla iş de yaratılabilir. İstihdamın genişlemesine katkı sağlayan bu etki "uyarılmış istihdam etkisi" olarak adlandırılmaktadır. ABD'de temiz enerji üzerindeki harcamaların direkt, endirekt ve uyarılmış etkilerle birlikte iş yaratmanın temel motoru olması beklenmektedir (Pollin vd., 2009, s.27; Bowen, 2012, s.9; Bird ve Lawton, 2009, s.6). Ancak, yeşil işlerin zamanlaması ve süresi sektörlere göre değişebilir. Örneğin inşaat, imalat ve kurulum işleri karşılaştırmalı olarak kısa dönemli ve geçici olabilirken, devam eden işletim, bakım ve yakıt işleme işleri üretim aktivitelerinin süresine bağlı olarak, görece daha uzun dönemli ve daha daimi olabilir (Bowen, 2012, s.9).

Dokuz ülke ve iki bölgede yapılmış ve alınmış politik önlemlere, metodolojik yaklaşımlara, ülkeye özel durumlara ve analizlerde kullanılan verilere dayanan 24 çalışma ve bir küresel analiz, yeşil ekonomiye geçişin önemli ölçüde net istihdam artışları sağlayabileceği sonucuna ulaşmıştır. Çalışmaların çoğunluğunda, çevresel reformlar tamamlayıcı hükümet politikaları ve vergiler, sübvansiyonlar ve çalışan eğitim ve öğretimini de içeren teşvikler ile beraber yürütülmüştür. İşgücü piyasası ve sosyal politikalar tamamlayıcı çevresel reformlar ve reformların istihdam üzerindeki negatif etkilerinin dengelenmesi ile uygulanmıştır. Bu bulgular, politik önlemlerin çevresel gelişmenin yanı sıra, istihdam artışı da sağlayarak, ekonomik faydanın artırılabileceğini göstermektedir (ILO, 2013b, s.29). Strietska-Ilina ve arkadaşlarının (2011) 21 ülke üzerinde yaptıkları araştırmada ise, yeşil ekonominin istihdam üzerinde pozitif ve negatif istihdam; yeni iş oluşturma ve mevcut işleri koruma; direkt ve endirekt istihdam; geçici ve uzun-dönemli işler olmak üzere dört temel etkisin olduğu tespit edilmiştir. Strietska-Ilina ve arkadaşlarının UNEP ve OECD çalışmalarından adapte ettiği çalışmalarında, yeşil ekonominin istihdam üzerindeki etkilerinin sınırlı bir fayda sunacağı ve bu etkilerin firmalar, endüstriler, bölgeler ve ülkelere göre değişebileceği ileri sürülmüştür. Yeşil ekonominin istihdam üzerindeki etkileriyle ilgili farklılıklar ve gözlemler Tablo 3'de gösterilmektedir. 
Tablo 3

Yeşil ekonominin istihdama etkilerinin tipleri

\begin{tabular}{|c|c|}
\hline \begin{tabular}{|l} 
Etkilerin Tipleri \\
\end{tabular} & Gözlemler \\
\hline $\begin{array}{l}\text { Pozitif ve negatif } \\
\text { istihdam etkileri }\end{array}$ & $\begin{array}{l}\text { - Yeşil politikalar ve işletme uygulamaları yeni işler yaratabilir veya } \\
\text { mevcut olanları koruyabilir } \\
\text { - Diğer taraftan çevre düzenlemelerinin teoride negatif sonuçları } \\
\text { (maliyetleri yükselterek, talebi azaltarak ya da bir fabrika veya } \\
\text { şirket rekabetsizliği oluşturarak) olabilir; ancak bunun fazlasıyla } \\
\text { nadir rastlanan bir sonuç olduğu kanıtlanmıştır. }\end{array}$ \\
\hline $\begin{array}{l}\text { Yeni iş oluşturma ve } \\
\text { mevcut işleri koruma }\end{array}$ & $\begin{array}{l}\text { - Yeşil işler bir ölçüde yeni teknolojilerin geliştirilmesi ve } \\
\text { yeni endüstrilerin ortaya çıkması (rüzgâr türbinleri, güneş } \\
\text { fotovoltaikleri, yakıt pilleri, biyo-yakıt vb.) ile oluşturulacaktır. } \\
\text { - Mevcut firmalar ve endüstriler işlemlerini yeşilleştiriyorken, } \\
\text { mevcut işler dönüştürülebilir ve böylece muhtemel kayılara } \\
\text { karş1 korunabilir (iş metotları, yeniden eğitimde değişimleri } \\
\text { uygulayarak). }\end{array}$ \\
\hline $\begin{array}{l}\text { Direkt ve endirekt } \\
\text { istihdam etkileri }\end{array}$ & $\begin{array}{l}\text { - Çevreyle ilgili harcamaların uyarılmasıla oluşacak talep ve çıktı } \\
\text { artışlarıyla işler direkt bir şekilde oluşturulabilir. } \\
\text { - Endirekt istihdam etkileri, tedarik sağlayan endüstrilerde ortaya } \\
\text { çıkmaktadır. } \\
\text { - Uyarılan iş etkileri, ücret gelirinin ilave endüstrilerde oluşturulan } \\
\text { talepler için harcanması ile oluşur. }\end{array}$ \\
\hline $\begin{array}{l}\text { Geçici ve uzun-dönemli } \\
\text { işler }\end{array}$ & $\begin{array}{l}\text { - Yapım ve montaj işleri (rüzgar türbini gibi) genellikle geçici bir } \\
\text { doğadadır (özel bir politika önlemi veya programınca desteklenen } \\
\text { işlerde olduğu gibi). } \\
\text { - Diğer taraftan, üretim ve bakım işleri daha uzun ömürlüdür. }\end{array}$ \\
\hline
\end{tabular}

Kaynak: Strietska-Ilina vd., 2011, s.56

Yeşil ekonomiye geçiş başarılırsa, buna paralel olarak, bir takım yeşil yakalı çalışan talebi de hızlı bir şekilde artabilir. UNEP raporunda, 2030 yılına kadar dünya çapında rüzgar enerjisi üretiminde 2,1 milyon iş, güneş enerjisinde 6,3 milyon iş ve bio-yakıtla ilgili tarım ve sanayide 12 milyon iş olmak üzere toplam yaklaşık 20 milyon işin yaratılabileceği bildirilmektedir. Avrupa Komisyonu'nun 2009'da yaptığ 1 bir çalışmada, 2020 yılında kadar enerji tüketiminin yaklaşık \%20'sinin yenilenebilir enerjiden karşılanması hedefi geçekleştirilse, bu sürede yaklaşık 2 milyondan daha fazla işin yaratılabileceği tahmin edilmektedir. 2010'da ABD'de yeşil iş ve hizmetlerde 3,1 milyon (işgücünün \%2,4'ü) işçi istihdam edilmiştir (Özsoy, 2011, s.24). 2010 'da ABD'de yapılan bir çalışmada yenilenebilir enerjinin portföyünün payı 2030'da kadar \%30'a ulaşırsa, sıkı enerji etkinliği politikaları ile birlikte, ABD enerji sektöründe 4 milyon iş artışı sağlanabileceği tahmin edilmektedir. Tabi bu rakamların yenilenebilir enerji sektöründe iş yaratma potansiyelini yansıttığı, aynı zamanda bu değişimin fosil yakıt ve enerji vb. sektörlerde iş kayıplarını da beraberinde getireceği akılda tutulmalıdır (ILO ve OECD, 2012, s.4-5; OECD, 2012, s.37). Almanya' da akaryakıt tüketimi ve 
$\mathrm{CO}_{2}$ emisyonu nispi olarak \%7'den \%2-2,5'e düşürülmüş ve özellikle emek yoğun sektörlerde, 1999-2003 boyunca, ekolojik vergi reformları sayesinde 250 bin iş yaratılmıştır. 1990-2010 yılları arasında istihdamdaki \%0,55'lik bir artış ve $\mathrm{CO}_{2}$ emisyonundaki \%2'lik bir azalma, enerji vergi gelirleri işgücü tarhına sosyal güvenlik katkılarını sübvanse etmek için geri dönüştürülerek sağlanmıştır. Endonezya' da enerji, ulaşım ve ormancılıkta yıllık \%2'lik bir yatırım, birçoğu yeşil iş olan düzgün çalışma koşulları olan dört sektörde 938.984 ila 1.270.390 arasında iş yaratması beklenmektedir (ILO, 2013b, s.30). Ayrıca, Japonya' da yeşil mal ve hizmetler sektöründeki 468 milyar \$'lı yeni yatırımlardan 1,4 milyon yeni iş yaratılmasını beklenmektedir. İngiliz Sanayi Konfederasyonu (CBI) raporuna (2012) göre, 2010/11'de İngiliz yeşil işletmeleri 3,3 trilyon $£$ (Great Britain Pound)' luk küresel pazar değerinden 122 milyar £'luk bir pay alarak, reel bazda büyümeye devam etmiş ve bu dönemde, bazı yatırımları ve işleri dönüştürerek, İngiltere'de yaklaşık 940 bin kişiye istihdam imkânı sağlanmıştır. Fakat bu büyüme, sektörler izole edilerek değil, tüm sektör ve bölgelere kendi aralarında kaynaştırılarak sağlanmıştır (CBI, 2012, s.8). Ayrıca aynı raporda, düşük karbonlu ekonominin İngiltere'de büyümenin gerçek motoru olabileceğini, ancak bu potansiyelin bazı riskleri de içinde barındırdı̆̆ 1 belirtilmiştir. $\mathrm{Bu}$ yüzden düşük karbonlu piyasalar ve yatırımlar değişen koşullara göre uyarlanmalı ve ekonomik değerleri maksimize etmek için stratejik bir yaklaşımla desteklenmelidir (CBI, 2012, s.2). Benzer şekilde, Çin'de yeşil endüstrilerin milli gelirdeki payının 2020'ye kadar \%2'den \%15'e çıkarılması ve net 10 milyon yeni yeşil işin yaratılması beklemektedir (ILO, 2013b, s.18). 2020 Biyo-çeşitlilik Stratejisine göre, yeşil ekonomik yapılanma istihdam üzerinde pozitif bir etkiye sahip olacak ve yeşil vasıflarda talep artışı olacaktır. Çevrenin korunmasına, yönetilmesine ve restore edilmesine katkı sağlayan çevresel politika reformları sürdürülebilir tarım, ormancılık ve balıkçılık, eko-turizm, deniz çevresi, çevresel izleme, doğa koruma, genetik kaynakların (ilaç ve kozmetik) kullanımı, yeşil altyapılar için mekansal planlama ve deniz alanını yönetmek için daha kaynak etkin yöntemler geliştirme alanlarında işgücü talebi artacaktır. Biyo-çeşitlilik ve eko-sistem hizmetlerindeki boş alanlar direkt ya da endirekt sağlanacak sayısız işler için önemli fırsatlar sunmaktadır. Örneğin AB, 14,6 milyon çalışanın biyo-çeşitlilik ve ekosistem hizmetlerinde istihdam edilebileceğini tahmin etmektedir (European Commission, 2012, s.9). 


\section{İstihdamın Niteliği Üzerindeki Olası Yansımaları}

Yeşil ekonomide istihdamın niceliği üzerine birçok çalışmaya kıyasla, istihdamın niteliği üzerine sınırlı sayıda bulgu bulunmaktadır. Tedarik endüstrilerinde endirekt işlerin ve enerji ve kaynak etkinliği ve tasarruflar yoluyla uyarılmış işlerin niteliğinin yeşil ekonomik yapılanmanın bir sonucu olarak değişmesi çok olası değildir. Ancak, iş artışları ve iş kayıplarının fonksiyonu, işin niteliğinde de değişimler meydana getirmektedir.

ABD'de yeşil işlerle yeşil olmayan işleri karşılaştıran bir çalışma, yeşil işlerin beceri ve ücret yönünden yeşil olmayan işlerden daha iyi çalışma koşulları sunduğu sonucuna ulaşmıştır. Benzer şekilde Çin, Almanya ve İspanya'y1 kapsayan bir araştırma yenilenebilir enerji sektörlerindeki işlerinin karşılaştırmalı olarak diğerlerinden daha nitelikli olduğunu bildirmiştir. Almanya ve İspanya'dan gelen veriler, yenilenebilir enerji sektörlerindeki işlerinin küçük bir bölümünün geçici olmasına karşın, büyük bir bölümünün daimi ve tam süreli olduğunu göstermektedir. Bu açıdan, her iki ülkedeki yenilenebilir enerji işleri ekonominin tümünden daha yüksek bir performansa sahiptir. Dahası, her iki ülkedeki çalışmalar yenilenebilir enerji sektöründeki işçilerin vasıf seviyelerinin, hem üniversite seviyeleri, hem de mesleki eğitim ve öğretim seviyeleri açısından, ulusal işgücü ortalamasından daha iyi olduğunu göstermektedir (ILO, 2013b, s.3334; Görmüş, 2016, s.1087). Yeşil ekonomide işin niteliği ve vasfı ile ilgili Avusturya, Almanya, Hollanda, İspanya ve İsveç’teki seçilen sektörlerdeki şirketler arasında yapılan bir araştırma, çalışma sürecinin ayrılmaz bir parçası olarak, çevresel koruma önlemlerini adapte etmenin, çalışma çevresi, çalışma süresi, iş organizasyonu ve iş sözleşmeleri yönünden işin niteliğini artırdığını bulmuştur. Bu çalışmanın sonucuna göre, atık yönetimi gibi bazı sektörlerde işin niteliği özellikle düşmüş olmasına rağmen, çevre mevzuatları birçok iş kolu üzerinde pozitif bir etki yaratmıştır. Bu anket, yeşil ekonomik yapılanmanın şirketlerin \%75'inde yüksek vasıflı çalışan talebi oluşturduğunu göstermiştir. $\mathrm{Bu}$ girişimciler operasyon, bakım organizasyon, mühendislik ve geliştirme, bilgi ve iletişim teknolojileri ve pazarlama konularında yeni vasıf gereklerini karşılamak için hem içsel (şirketlerin \%68'i), hem de dişsal (şirketlerin \%11'i) eğitim hizmetlerini artırmak zorunda kalmışlardır (Strietska-Ilina vd., 2011, s.23; Görmüş, 2016, s.1085). 
Avrupa Yaşam ve Çalışma Koşullarını Geliştirme Vakfı tarafından 145 katılımc i ile iklim değişikliğinin işlerin niteliği üzerine internet üzerinden yapılan bir anket, iklim değişikliğinin işlerin niteliği üzerindeki etkisinin kayda değer olmadığını bulmuştur. Çalışmada katılımcıların \%39'u yeşil iş uygulamalarıyla çalışanların iş niteliğinin aynı olduğunu ifade ederken, katılımcıların \%38'i de yeşil iş uygulamalarıyla çalışanların iş niteliğinin farklı olduğunu belirtmiştir. Ancak, yeşil ekonomiye geçişin işin niteliği üzerindeki etkisi, geleneksel endüstrilerden ziyade, yeşil endüstrilerde daha önemli olabilir. Örneğin, yeşil endüstrilerde istihdam edilen işçiler güvenli çalışma için yeterli beceri ve iş tecrübesine sahip olmayabilirler ve onların çalışma koşulları geleneksel endüstrilerde diğer çalışanlardan daha kötü ve daha az kontrol edilebilir olabilir. Bunu olası nedenleri şöyle sayılabilir (Gaušas vd., 2012, s.28):

- Düşük sendikal yoğunluk veya sendikanın olmaması, kapsamı dar toplu iş sözleşmesi, zayıf örgütlenme ve sosyal diyalogdan dolayı yeşil işlerdeki işçiler daha düşük temsil, örgütlenme ve korumayla karşı karşıya kalabilirler.

- Yeşil işlerdeki işçiler özellikle KOBİ'ler ve yenilenebilir enerji sektörlerinde kayıt dışı geçici işler veya bağımsız çalışmanın yaygın türlerinden karşılaştırmalı olarak daha fazla mustarip olabilirler.

- Yeşil endüstrilerdeki KOBİ’lerin çoğunluğu göreceli olarak sağlık ve güvenlik açısından daha az bilinç ve uzmanlığın yanı sıra, işyeri risk değerlendirmeleri vb. gibi konularda büyük ölçekli işletmelerden daha kötü çalışma koşulları sunabilir.

Yeşil sektörlerdeki işin niteliği, yeşil sektörlerin istikrarsız, KOBİ'lerin ekonomik dalgalanmalara karşı dayanıksız olması, politik hedef ve düzenlemelerdeki sürekli değişim ve sendikalaşmanın engellenmesinden dolayı hala belirsizdir. Bütün bunlara rağmen, önemli kaynaklarına odaklanan işletmelerdeki yüksek vasıf gerektiren işlerde, işletmelerin yenilik hevesi işlerin niteliği üzerinde olumlu bir etki oluşturabilir. Ayrıca, eğer yeşil ekonomik yapılanma kamu otoriterince teşvik edilir ve desteklenirse, daha iyi ve daha yüksek nitelikli çalışma koşulları için bir kültür yaratılmasına ve yaşam koşullarının geliştirilmesine katkı sağlanabilir. Örneğin, kamu otoriteleri yeşil kamu yatırımlarında yeşil işlerin niteliği ile ilgili gereklilikleri belirleyerek, öncü bir rol oynayabilir (Gaušas vd., 2012, s.28-29). 
Yeşil yeniden yapılanmanın işlerin niteliği üzerindeki yansıması, işlerin tipine (ofis işleri pozitif bir şekilde etkileniyorken, şantiye işleri negatif olarak etkilenebilir), işçilerin vasıf seviyelerine (vasıf düzeyi ne kadar düşerse, nitelikli bir iş bulma şansı o kadar azalmaktadır) ve meslek yapılarına (bir pozisyonun mevkisi yükseldikçe, ekonomik yeşillenmenin meslek üzerindeki pozitif etkisi o kadar artmaktadır) göre de değişkenlik gösterebilir. Ancak, düşük vasıflı işçilerin, yeni beceriler kazandırılarak ya da kamu veya işverenlerce sağlanan eğitimler yoluyla mevcut becerileri geliştirilerek, yeni gelişen yeşil sektörlerde iş bulma firsatları artırılabilir. Ayrıca, yeşil sektörler yüksek vasıflı işçilerin yanı sıra, günlük ve fiili rutin işleri doldurmak için düşük vasıflı işçilere de ihtiyaç duyacaktır. Bunu yapmak için, işyeri içi ve dışı eğitimlerle, vasıf sevileri devamlı güncel tutularak, çalışanlar vasıf düşmesine karşı korunmalıdırlar. Yüksek vasıflı işçilere gelince, jenerik vasıflara sahip çalışanlara ihtiyaç duyan yeşil sektörlerde iş bulma açısından, onlar diğerlerinden daha fazla şansa sahip gibi gözükmektedir (European Commission, 2012, s.10).

\section{İstihdamda Cinsiyet Eşitsizliği Üzerindeki Olası Yansımaları}

Toplumsal cinsiyet eşitliği, eşitliğin sadece içsel bir değer ve kendi içinde bir hak temelinde değil, aynı zamanda sürdürülebilir kalkınmanın sağlanması ve yoksulluğun ve açlığın önüne geçilmesi de dâhil olmak üzere, Milenyum Kalkınma Hedeflerine (Millennium Development Goals) ulaşılması için temel şartlardan biridir. Diğer taraftan, ekonomik kalkınma tüm yönleriyle tutarlı bir cinsiyet eşitliği ile kaynaştırılmazsa, yeşil ekonomide sürdürülebilir bir kalkınmanın sağlanması mümkün değildir. Bu nedenle, yeşil ekonomiyi geliştirmeye yönelik stratejiler ve yaklaşımların, toplumsal cinsiyet yaklaşımı ile tam olarak örtüşmesi gerekmektedir. Bu açıdan cinsiyet eşitliği, yeşil ekonomiye geçişte ve düzgün çalışma koşullarını sağlayan yeşil işlerin yaratılması yoluyla, birey ve toplumun yaşam koşullarının iyileştirilmesi hedefinin tam merkezinde yer almalıdır (ILO, 2015, s.1). Yani, sürdürülebilir kalkınmanın ücret ve cinsiyet eşitliğine dayanan sosyal boyut ile bütünleşmesi sağlanmadan, yeşil ekonomi stratejilerinin sürdürülebilir kalkınmanın motoru olması oldukça zor gözükmektedir (Stevens, 2009, s.4).

Yeşil ekonomiye başarılı bir geçiş ve sürdürülebilir kalkınmanın gerçekleştirilmesinin yanı sıra, kadınların sosyal refahının sağlanması 
için cinsiyet eşitsizliğinin yapısal olarak ele alınması gerekmektedir. Yeşil ekonomiye geçiş istihdamda cinsiyet eşitliğini sağlayacak uygun sosyal politikalarla desteklenmezse, bu durum genel sürdürülebilirliğe zarar vererek, mevcut toplumsal cinsiyet eşitsizliklerinin daha da derinleşmesine yol açabilir. Bu nedenle, erkek ve kadın, emek ve sermaye, gelişmiş ve az gelişmiş ülkeler arasında daha eşit bir gelir paylaşımı sunmayı hedefleyen yeşil büyüme stratejilerinin başarılı olması, cinsiyet eşitliğinin de tam anlamıyla karşılanması bakımından son derece önemlidir. Bu yüzden, yeşil ekonominin yaratacağı toplumsal cinsiyet eşitsizliklerini gidermek için hükümetlere büyük iş düşmektedir (Stevens, 2012).

Bird ve Lawton'nun (2009) İngiltere'de LFS'den faydalanarak yaptıkları çalışmada, özellikle düşük karbonlu inşaat ve imalat gibi büyüyen yeşil sektörlerde kadın istihdam olasılığının (sırasıyla \%14 ve \%20) düşük olduğunu ve kadınların, cinsiyet temelli mesleki ayrımcılık nedeniyle, gelecekte de bu sektörlerden dişlanabileceklerini ileri sürmüşlerdir (Bird ve Lawton, 2009, s. 6-7). Bird ve Lawton'na (2009) göre, kadınların işgücü piyasasındaki varlığı, kısmi süreli çalışmanın kapsamı ile yakından ilişkilidir. LFS, tüm işlerin yaklaş1k 1/4'ünün kısmi süreli işlerden oluştuğunu göstermekle birlikte, hem inşaat, hem de imalat sektörlerindeki işlerin sadece \%7'si kısmi süreli çalışanlar tarafından yapılmaktadır. Bu açıdan, inşaat ve imalat sektörlerinde kısmi süreli ve esnek istihdam olanaklarının kısıtlı olması, birçok kadının bazı düşük karbonlu sektörlerdeki yeşil işlerden dışlanmalarına sebep olmaktadır (Bird ve Lawton, 2009, s. 26).

2030 y1lına kadar, kamu ve özel sektörün enerji yoğunluğunu azaltmaya, israfı en aza indirmeye ve eko-sistemi korumaya ve restore etmeye yönelik yenilenebilir enerji, orman koruma ve rehabilitasyon, su ve sanitasyon altyapısı, yeşil konut ve çevre düzenlemesi gibi sektörlerde veya alanlarda dünya çapında 20 milyon yeni yeşil iş yaratması beklenmektedir. Ancak, yeşil ekonominin bazı alanları, sunulan iş imkânları nedeniyle büyük ölçüde kadınlara kapalıdır. Örneğin, kadınlar teknik personelin \%6'sından ve üst düzey yöneticilerin \%1'inden daha azını oluşturdukları enerji sektöründe uzun süredir marjinal çalışan konumuna itilmişlerdir. Ayrıca, kadınlar küresel inşaat işlerinin \%9'undan daha azında çalışmaktadırlar ve yaptıkları işler daha çok idari ve sekreterlik işleridir (Stevens, 2009, s.9). Bununla birlikte, yeşil işlerin yaklaşık \% 75 'inin yenilenebilir enerji ve yeşil bina inşasıyla ilgili 
olması beklenmektedir ve yeşil ekonomideki vasıflı enerji ve inşaat işleri pozisyonları genellikle erkek egemenliğindedir. Geleneksel olarak kadın egemenliğinde olan sekreterlik, öğretmenlik, hemşirelik ve ev yardımı gibi meslekler yeşillendirilse bile, bu meslekler yeşil ekonomide iş yaratmanın temel bileşenleri arasında görülmemektedir (Stevens, 2012).

Tarım ve ormancılık gibi sektörlerin yeşil ekonomi içinde büyük bir paya sahip olması ve organik tarım, biyo-yakıtlar ve ormanların korunması gibi alanlarda en az 2 milyon yeşil işin yaratılması tahmin edilmektedir. Ancak tarım, ormancılık, eko-turizm ve diğer kaynak bazlı sektörlerde birçok yeşil iş yaratılsa bile, kadınların gelişmekte olan ülkelerdeki marjinal statüsü, bu yeni iş firsatlarının değerlendirilmesini büyük ölçüde engellemektedir (Stevens, 2012). Diğer taraftan, yeşil ekonominin toplumun tüm kesimlerini "içerleyici" özelliği, kadınların işgücünde hak ettikleri yerleri kazanmaları için iyi bir firsat da yaratabilir. Teorik olarak, kadınlar ekonominin birincil, ikincil ve üçüncül sektörlerinde tüm yeşil iş kategorilerinde çalışabilirler. Çoğu yeşil işin ağır işçilik gerektirdiği ve bunun kadın istihdamının önünde bir engel oluşturduğuna dair bir takım algılara rağmen, otomasyon günümüzde fiziksel güç ihtiyacını büyük oranda azaltmıştır. Ancak, yeşil işlerin büyük çoğunun, kadın istihdamının önemli ölçüde daha düşük olduğu inşaat, imalat ve mühendislik alanlarında olması, yeşil ekonominin yaratacağı bu işlerin herhangi bir kasıt olmaksızın kadınları dışlaması beklenmektedir (Stevens, 2009, s.7).

\section{Yöntem}

\section{Veri}

$\mathrm{Bu}$ çalışmada, geniş kapsamlı hane halkı temelli bir araştırma olan ve İngiliz Ulusal İstatistik Ofisi (ONS) tarafından yılda 4 kez düzenli şekilde yayınlanan 2014 yılı LFS mikro verisi kullanılmıştır. Sendika üyeliği ve toplu iş sözleşmesi kapsamı ile ilgili sorular sadece 4. çeyrekte sorulduğu için çalışmada 2014 4. çeyrek (Ekim-Aralık) verisinden faydalanılmıştır. 799 sorudan oluşan bu anket formu 95.704 katılımcı tarafından doldurulmuş olup, araştırmanın bağımlı değişkeni olan yeşil işleri sorgulamak için toplam istihdam edilen 45.285 katılımcı içinden yeşil işlerde istihdam edilen 684 kadın ve 2.346 erkekten iki ayrı gözlem grubu oluşturulmuştur. Bu araştırmanın metodolojisi temel olarak, ONS'dan alınan 2014 yıllarına ait LFS mikro 
verilerini kullanarak, demografik profil ve istihdam durumu değişkenlerinin yeşil işlerle ilişkisindeki cinsiyet farklılıklarının ki-kare ve iki yönlü lojistik regresyon modelleme yöntemleri ile analiz edilmesine dayanmaktadır.

\section{Bağımlı ve Bağımsız Değişkenler}

İngiltere'de çevresel, ekolojik, yenilenebilir, sürdürülebilir, temiz, düşük karbonlu ya da karbonsuz ekonomik aktiviteleri içeren "düşük karbonlu çevresel mal ve hizmetler sektörlerinin" haritalandırmasını yapan İş, Yenilik ve Beceri Departmanı'na (BIS) (2013) göre, “yeşil sektörler” diğer sektörlerden kesin çizgilerle ayrılabilen belirli sınırları olmayan, esnek ya da şemsiye bir kavramdır. Bu açıdan çalışma kapsamında, yeşil sektörlerdeki istihdam durumunu sorgulamak için bağımlı değişkenimiz olan "yeşil işler", 4 haneli endüstri kodlarından türetilmiştir. Bu kapsamda, EK'teki çevreci, yenilenebilir, sürdürülebilir, temiz teknolojili ve düşük karbonlu olduğu düşünülen 45 ekonomik aktivitedeki işler " $Y=l$ " koduyla yeniden kodlanırken, geri kalan sektörlerdeki işler de, " $Y=0$ " kodu ile yeniden kodlanmıştır. İngiltere'deki tarım sektörü yetersiz örneklem büyüklügünden dolayı bu analize dâhil edilmemiştir. Ayrıca, bu çalışmada yeşil olarak seçilen ekonomik aktivitelerin Tablo 2'deki yeşil iş göstergelerini tüm boyutlarıyla taşıdığını düşünmek teknik olarak mümkün değildir. Ancak, yine de İngiltere'de yeşil sektörlerdeki istihdamla ilgili bulgulara ulaşmanın en iyi yolu LFS olduğu için seçilen sektörlerin yeşil işleri en iyi şekilde temsil ettiği varsayılmıştır.

Analizde kullanılan demografik profil (yaş, çalışılan ülke, eğitim durumu) ve istihdam durumu (çalışma şekli, işyeri ölçeği, özel/kamu sektörü, sendika üyeliği, toplu iş sözleşmesi kapsamı durumu ve meslekler) bağımsız değişkenleri, katılımcıların kendi beyanlarından alınmıştır. Ayrıca, daha anlamlı sonuçlar elde etmek için yaş bantları, eğitim durumu, işyeri ölçeği ve meslek değişkelerinin bazı kategorileri birleștirilerek, kullanılmıştır.

\section{Analiz Tekniği}

Lojistik regresyon bağımlı değişken ile bir dizi bağımsız değişkenler (öngörücü veya açıklayıcı) arasındaki ilişkiyi tanımlamak için, en az değişken ile en iyi uyuma sahip makul modeli bulmaya yönelik kullanılan istatistiksel bir yöntemdir. İki yönlü (binary) lojistik regresyonda bağımlı değişken iki çatallıdır (dichotomous) (Hosmer ve Lemeshow, 2000, s.1). Bu 
açıdan, bu çalışmadaki bağımlı değişkenimiz ikili tepki sistemine göre, “yeşil sektörlerdeki işler" ya da "geri kalan sektörlerdeki işler" biçimindedir. Bu kapsamda oluşturulan lojistik modeller, yeşil işler ile bu çalışmada kullanılan bir dizi demografik ve istihdamla ilgili değişkenler arasındaki ilişkideki cinsiyet farklılıklarını tahmin etmektedir. Tablo 5'deki bağımsız değişkenler, yeşil işler ile olan ilişkilerinin gözlemlenmesine ve her bir kategorinin bu ilişkideki nispi anlamlılığının, referans kategoriye göre, değerlendirilmesine olanak sağlayan tümü, erkek ve kadın için ayrı bloklarda oluşturulmuş modellere uygulanmıştır.

Lojistik regresyonda, modellerin uyum iyiliği (the goodness of fit), gözlemlenen ve tahmini beklenen frekansın gx2 tablosundan Pearson kikare istatistiği hesaplanarak elde edilen Hosmer-Lemeshow istatistiği ile sağlanmıştır. Hosmer-Lemeshow istatistiği, uyumlu lojistik regresyon modeli doğru model olduğunda, Hosmer-Lemeshow istatistiğinin dağılımının ki-kare dağılımının g-2 serbestlik derecesi ile iyi bir şekilde yaklaştığını göstermektedir (Hosmer ve Lemeshow, 2000, s.148-149). Bu açıdan, Hosmer-Lemeshow test sonucunun anlamlı olmaması $(\mathrm{p}>, 05)$, modelin uyum iyiliğini sağladığını göstermektedir.

\section{Araştırma Sonuçları}

\section{Betimleyici Analiz}

Tablo 4'te yeşil işler ile bu çalışmada kullanılan demografik ve istihdam durumu değişkenleri arasındaki ilişkide, cinsiyet eşitsizliklerinin anlamlı olup olmadığı sosyal bilimlerde çok yaygın şekilde kullanılan ki-kare bağımsızlık testi ile incelenmiştir. Tablo 4'e göre, tüm kategorilerde yeşil işlerde erkek istihdamının, kadınlara göre, anlamlı bir şekilde daha yüksek oranlarda gerçekleştiği gözlenmektedir. Bu durum İngiltere'de yeşil işlerin erkek egemenliğinde olduğuna ve dolayısıyla istihdamda bir cinsiyet eşitsizliği oluşturduğuna işaret etmektedir.

Yaş grupları değişkeni incelendiğinde, yaş grupları ile yeşil işler arasında kadınlar aleyhine anlamlı bir cinsiyet eşitsizliği olduğu görülmektedir ( $\mathrm{p}<$ ,001). Ayrıca kadın ve erkekte yaş ilerledikçe, yeşil işlerde istihdam oranlarının da giderek arttığı izlenmektedir. Buna göre, yeşil işlerde istihdam oranı kadınlarda 25-34 yaş bandında $(\% 3,5)$ daha yüksekken, erkekte 55-64 yaş 
bandında $(\% 11,6)$ daha yüksektir. 16-24 yaş arası gençler, her iki cinsiyette de yeşil işlerdeki istihdam oranının en düşük olduğu yaş grubudur.

Tablo 4 ülkeler yönüyle irdelendiğinde, yeşil işler ile çalışılan ülke ilişkisinde kadınlar aleyhine anlamlı bir cinsiyet eşitsizliği bulunmaktadır ( $\mathrm{p}<$ ,001). Yeşil işlerdeki cinsiyet eşitsizliğinin en yüksek olduğu ülke Galler'dir. Buna göre, erkeklerin \% 12,5'inin Galler'deki yeşil işlerde çalışması, kadınlara kıyasla (\%2), anlamlı bir şekilde daha yüksek gözlenmektedir.

Tablo 4

Yeşil işlerin cinsiyetler arasındaki dağılım oranları

\begin{tabular}{|c|c|c|c|c|c|}
\hline \multirow{2}{*}{ Değişkenler } & \multirow{2}{*}{ Kategoriler } & \multicolumn{2}{|c|}{ Kadın } & \multicolumn{2}{|c|}{ Erkek } \\
\hline & & $\mathrm{N}^{\mathrm{a}}$ & $\%{ }^{\mathrm{b}}$ & $\mathrm{N}^{\mathrm{a}}$ & $\%^{b . c}$ \\
\hline \multirow{6}{*}{ Yaş Bantları } & $16-24$ & 45 & 1,9 & 284 & $6,4 * * *$ \\
\hline & $25-34$ & 165 & 3,5 & 926 & $10 * * *$ \\
\hline & $35-44$ & 170 & 3,3 & 1.080 & $10,1 * * *$ \\
\hline & $45-54$ & 174 & 3 & 1.216 & $10,7 * * *$ \\
\hline & $55-64$ & 105 & 2,9 & 934 & $11,6 * * *$ \\
\hline & $64+$ & 25 & 3,4 & 252 & $11,3 * * *$ \\
\hline \multirow{4}{*}{ Çalışılan Ülke } & İngiltere & 595 & 3,2 & 3.970 & $10,2 * * *$ \\
\hline & Galler & 20 & 2 & 246 & $12,5^{* * *}$ \\
\hline & \begin{tabular}{|l|} 
İskoçya \\
\end{tabular} & 58 & 2,9 & 360 & $9,7 * * *$ \\
\hline & Kuzey İrlanda & 11 & 1,4 & 116 & $7,5 * * *$ \\
\hline \multirow{5}{*}{ Eğitim durumu } & Üniversite veya eșdeğeri & 296 & 4,1 & 1.596 & $11,7 * * *$ \\
\hline & \begin{tabular}{|l|} 
Lise \\
\end{tabular} & 58 & 2,4 & 526 & $12,6^{* * *}$ \\
\hline & Ortaokul & 262 & 2,7 & 1.852 & $9 * * *$ \\
\hline & Diğer eğitimler & 33 & 2,1 & 400 & $9,2 * * *$ \\
\hline & Eğitimi olmayan & 25 & 2,2 & 258 & $9,4 * * *$ \\
\hline \multirow{2}{*}{ Çalışma Şekli } & Kismi süreli & 211 & 2,2 & 418 & $6,8 * * *$ \\
\hline & Tam süreli & 473 & 3,8 & 4.274 & $10,7 * * *$ \\
\hline \multirow{5}{*}{ İşyeri Ölçeği } & 1-10 mikro ölçek & 132 & 3,2 & 742 & $9,5 * * *$ \\
\hline & 11-49 kücük ölccek & 122 & 2,2 & 876 & $9,5 * * *$ \\
\hline & 50-249 orta ölçek & 134 & 2,9 & 884 & $9,6^{* * *}$ \\
\hline & 250-499 büyük ölçek & 46 & 3,7 & 292 & $9,7 * * *$ \\
\hline & 500 ve üzeri büyük ölçek & 131 & 3,6 & 730 & $10,3 * * *$ \\
\hline \multirow{2}{*}{ Çalıştığı Sektör } & Özel Sektör & 604 & 4 & 4.366 & $11,2 * * *$ \\
\hline & Kamu Sektörü & 78 & 1,1 & 314 & $4,6 * * *$ \\
\hline \multirow{4}{*}{\begin{tabular}{|l|} 
Sendikalılık \\
Durumu \\
Toplu iş sözleşmesi \\
(TíS) Kapsamı \\
\end{tabular}} & Sendika üyesi & 70 & 1,4 & 728 & $9,5 * * *$ \\
\hline & Sendika üyesi değil & 503 & 3,7 & 3.202 & $10,4 * * *$ \\
\hline & TIS kapsamında & 94 & 2 & 772 & $10,2 * * *$ \\
\hline & TİS kapsamında değil & 348 & 3,3 & 1.974 & $9,4 * * *$ \\
\hline \multirow{6}{*}{ Meslekler } & Yönetici ve profesyoneller & 221 & 3,5 & 1.876 & $12,7 * * *$ \\
\hline & $\begin{array}{l}\text { Teknisyenler ve yardımcı profesy- } \\
\text { oneller }\end{array}$ & 110 & 4 & 540 & $7,8^{* * *}$ \\
\hline & İdari ve sekreterlik meslekleri & 220 & 5,5 & 122 & 5,6 \\
\hline & $\begin{array}{l}\text { Vasıfll ticaret işleri, personel, satış ve } \\
\text { tüketici hizmetleri }\end{array}$ & 85 & 1,3 & 1.220 & $10 * * *$ \\
\hline & Süreç, tesis ve makine operatörleri & 21 & 5,6 & 526 & $10,4 * *$ \\
\hline & $\begin{array}{l}\text { Nitelik gerektirmeyen genel işlerde } \\
\text { çlıșanlar }\end{array}$ & 27 & 1,2 & 404 & $8,2 * * *$ \\
\hline
\end{tabular}

Kaynak:2014 (Q4/Autumn) İngiliz İşgücü Anketi’nden yazarın kendi analizi a Örneklem büyüklüğü ağırlıklıdır.

b Her bir değişken kategorisinin yüzde (\%) dağılımı.

c Ki kare sonuçları her bir satırda erkek ve kadın için: ${ }^{*} \mathrm{p}<, 05 ; * * \mathrm{p}<, 01 ; * * * \mathrm{p}<, 001$ 
Eğitim durumu ve yeşil işler ilişkisinde kadınlar aleyhine anlamlı bir cinsiyet eşitsizliği olduğu görülmekle $(p<, 001)$ birlikte, her iki cinsiyette de eğitim durumundaki artışın yeşil işlerdeki istihdam olasılığını kayda değer bir biçimde artırdığı gözlenmektedir. Bu açıdan, üniversite ve eşdeğer eğitim düzeyine sahip olan erkeklerin \%11,7'sinin yeşil işlerde çalışması, aynı eğitim düzeyindeki kadınlara $(\% 4,1)$ oranla, önemli ölçüde daha yüksektir. Bu durum, İngiltere'de yeşil işlerin daha çok eğitim seviyesi yüksek, vasıflı erkek işgücü talep ettiğini göstermektedir.

Tablo 4'e göre, çalışma şekli, işyeri ölçeği ve çalışılan sektör ile yeşil işler arasındaki ilişkide kadınlar aleyhine anlamlı bir eşitsizlik bulunmaktadır $(\mathrm{p}<$ ,001). Buna göre, tam süreli çalışan erkeklerin \%10,7'sinin yeşil sektörlerde istihdam edilmesi, kadınlara $(\% 3,8)$ göre, önemli ölçüde daha yüksek gözükmektedir. Benzer şekilde, özel sektörde istihdam edilen erkelerin \%11,2'sinin yeşil sektörlerde istihdam edilmesi, kadınlara (\%4) oranla daha yüksek beklenmektedir. Diğer taraftan, her iki cinsiyet için büyük ölçekli işyerlerinin yeşil işler sunması, diğer işyeri ölçeklerine göre, daha yüksek gözlenmektedir. Ancak, bütün işyeri ölçeği kategorilerindeki yeşil işlerde erkek istihdamı, kadın istihdamından anlamlı şekilde daha yüksektir.

Yeşil işler ile sendikalılık durumu ve TİS kapsamı ilişkisi açısından, kadınlar aleyhine anlamlı eşitsizlikler izlenmekle $(\mathrm{p}<, 001)$ birlikte, sendika üyesi erkeklerin $\% 9,5$ 'inin yeşil işlerde istihdam edilmesi, kadınlara $(\% 1,4)$ kıyasla, anlamlı bir şekilde daha yüksektir. Benzer şekilde, TİS kapsamındaki erkeklerin \%10,2'sinin yeşil işlerde çalışması, kadınlara (\%2) göre, anlamlı bir şekilde yüksek bulunmuştur.

Son olarak, tabloya meslekler açısından bakıldığında ise, yeşil işler ile yöneticilik ve profesyonel meslekler; teknisyen ve yardımcı profesyonel meslekler ve vasıf gerektirmeyen genel meslekler açısından, kadınlar aleyhine anlamlı eşitsizlikler bulunmaktadır $(p<, 001)$. Yeşil işlerdeki cinsiyet eşitsizliğinin en çarpıcı biçimde görüldüğü meslek grubu yöneticiler ve profesyonel meslekler grubudur. Buna göre, yönetici ve profesyonel meslek mensubu erkeklerin \%12,7'sinin yeşil işlerde istihdam edilmesi, kadınlara $(\% 3,5)$ kıyasla, oldukça yüksek beklenmektedir. Diğer taraftan idari ve sekreterlik meslekleri $(\% 5,5)$ ile süreç, tesis ve makine operatörlügüü işlerinin $(\% 5,6)$, kadınların yeşil işlerdeki istihdam olanaklarını diğer meslek gruplarına göre, daha fazla artırdığı gözden kaçmamaktadır. 
Tablo 4 genel olarak incelendiğinde, yeşil işlerdeki istihdam oranları erkeklerde kadınlardan anlamlı şekilde daha yüksek gözükmektedir. Bu açıdan Tablo 4'te kullanılan demografik profil ve istihdam durumu değişkenleri arasında İngiltere'de kadınların yeşil işlerde istihdam edilme oranlarının değişen derecelerde, erkeklere kıyasla, oldukça düşük olduğu görülmektedir.

\section{Lojistik Regresyon Analizi}

$\mathrm{Bu}$ çalışmada kullanılan demografik ve istihdam durumu değişkenleri ile yeşil işler ilişkisindeki cinsiyetler arasındaki farklılıkları inceleyen lojistik regresyon modelleri Tablo 5'te verilmiştir. Tabloda her bir kategorinin yeşil sektörlerdeki istihdam olasılığı ve anlamlılık düzeyleri, katsayılar, standart hata, Wald istatistikleri ve modellerin Hosmer ve Lemeshow test değerleri gösterilmektedir. Tabloda her bir değişken için son kategori referans kategori olarak tanımlanmıştır. Lojistik regresyon modellerinin değişken seçiminde Adımsal (Stepwise) Yöntemlerden İleriye Doğru Olabilirlik Oranı (Forward Likelihood Ratio) kullanılmıştır. Modellerde tahmin edilen değişkenlerin analize alınmasının önemli olup olmadığı Wald istatistiği ile sınanmış olup, kullanılan değişkenlerin modellere anlamlı katkılar sağladığı görülmüştür. Hosmer ve Lemeshow test sonuçları da (tümü için 0,760 > 0,05; erkek için $0,180>0,05$ ve kadın için $0,371>0,05)$ modellerin uyum iyiliğini sağladığını göstermektedir.

Tümü ve erkek için oluşturulan modeller, yaş değişkeninin yeşil işlerdeki istihdam olasılığını tahmin eden önemli bir değişken olduğunu göstermektedir. Diğer taraftan, kadın için oluşturulan model ise, yaş bantları ile yeşil işlerde istihdam olasılığını açıklayan herhangi bir anlamlı ilişki bulamamıştır. Tümü ve erkek için oluşturulan modellerde, yaş bantları arttıkça, yeşil işlerdeki istihdam olasılığının da lineer bir modda arttığı gözlenmektedir. Buna göre, 16-24 yaş bandındaki gençlerin tümünde $(\mathrm{OR}=0,479, \mathrm{p}<, 001)$ ve erkekte $(\mathrm{OR}=0,536, \mathrm{p}<, 001)$ yeşil işlerde istihdam edilme olasılığının, 64 yaş üstündekilere göre, anlamlı şekilde daha düşük olduğu görülmektedir.

Tümü ve erkek için oluşturulan modellerde, çalışılan ülke değişkenin yeşil işlerdeki istihdam olasılığını açıklayan önemli bir değişken olduğu izleniyorken, kadın için oluşturulan model ise, çalışılan ülke ile yeşil işlerdeki istihdam olasılığını açıklayan herhangi bir ilişki tespit edememiştir. $\mathrm{Bu}$ açıdan, Galler'deki erkeklerin $(\mathrm{OR}=2,303, \mathrm{p}<$,001) yeşil işlerde istihdam 
edilme olasılığı, Kuzey İrlanda' daki erkeklere göre, anlamlı şekilde 2 kattan daha yüksek gözükmektedir.

Tablo 5

Lojistik regresyon modelleri

\begin{tabular}{|c|c|c|c|c|c|c|c|c|c|c|c|c|}
\hline & \multicolumn{4}{|c|}{ Tümü } & \multicolumn{4}{|c|}{ Erkek } & \multicolumn{4}{|c|}{ Kadın } \\
\hline & B & St. Hata & $\begin{array}{l}\text { Wald } \\
\text { Testi }\end{array}$ & $\begin{array}{l}\text { Odds } \\
\text { Oran1 }\end{array}$ & B & St. Hata & $\begin{array}{l}\text { Wald } \\
\text { Testi }\end{array}$ & $\begin{array}{l}\text { Odds } \\
\text { Oran1 }\end{array}$ & B & St. Hata & $\begin{array}{l}\text { Wald } \\
\text { Testi }\end{array}$ & $\begin{array}{l}\text { Odds } \\
\text { Oran1 }\end{array}$ \\
\hline Yaş Bantları & & & 27,093 & $* * *$ & & & 15,115 & $* *$ & & & & \\
\hline $16-24$ & $-0,73$ & 0,18 & 16,601 & $0,479 * * *$ & $-0,62$ & 0,20 & 9,386 & $0,536^{* *}$ & & & & \\
\hline $25-34$ & $-0,54$ & 0,16 & 11,428 & $0,582 * * * \mid$ & $-0,43$ & 0,18 & 5,854 & $0,647 *$ & & & & \\
\hline $35-44$ & $-0,50$ & 0,15 & 10,127 & $0,605 * * *$ & $-0,46$ & 0,17 & 6,966 & $0,626^{* *}$ & & & & \\
\hline $45-54$ & $-0,42$ & 0,15 & 7,272 & $0,655^{* *}$ & $-0,35$ & 0,17 & 4,092 & $0,701 *$ & & & & \\
\hline $55-64$ & $-0,28$ & 0,15 & 3,233 & 0,751 & $-0,25$ & 0,17 & 2,120 & 0,772 & & & & \\
\hline $64+$ & I & $\mathrm{I}$ & I & $\mathrm{I}$ & $\mathrm{I}$ & $\mathrm{I}$ & $\mathrm{I}$ & $\mathrm{I}$ & $\mathrm{I}$ & $\mathrm{I}$ & I & 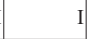 \\
\hline Çalışılan Ülke & & & 12,239 & ** & & & 15,797 & $* * *$ & & & & \\
\hline İngiltere & 0,48 & 0,17 & 7,944 & $1,616^{* *}$ & 0,41 & 0,19 & 4,523 & $1,511 *$ & & & & \\
\hline Galler & 0,70 & 0,20 & 12,134 & $2,032 * * * \mid$ & 0,83 & 0,22 & 13,237 & $2,303 * * * \mid$ & & & & \\
\hline İskoçya & 0,50 & 0,18 & 7,293 & $\mid 1,663^{* *}$ & 0,49 & 0,21 & 5,216 & $1,635^{*}$ & & & & \\
\hline Kuzey İrlanda & $\mathrm{I}$ & $\mathrm{I}$ & I & I & $\mathrm{I}$ & I & $\mathrm{I}$ & I & $\mathrm{I}$ & I & I & 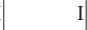 \\
\hline Eğitim Durumu & & & 32,239 & $* * *$ & & & 28,207 & $* * *$ & & & 13,870 & $* *$ \\
\hline Üniversite veya eşdeğeri & 0,52 & 0,14 & 13,642 & $1,688^{* * *} \mid$ & 0,44 & 0,15 & 7,745 & $\left|1,554^{* *}\right|$ & 0,69 & 0,32 & 4,490 & $2,005 *$ \\
\hline Lise & 0,43 & 0,15 & 8,312 & $1,549 * *$ & 0,38 & 0,17 & 5,044 & $1,466^{*}$ & 0,44 & 0,35 & 1,567 & 1,554 \\
\hline Ortaokul & 0,19 & 0,13 & 2,109 & 1,214 & 0,05 & 0,14 & 0,159 & 1,061 & 0,29 & 0,32 & 0,814 & 1,336 \\
\hline Diğer eğitimler & 0,10 & 0,15 & 0,482 & 1,116 & 0,01 & 0,17 & 0,004 & 1,012 & 0,11 & 0,38 & 0,092 & 1,124 \\
\hline Eğitimi olmayan & I & $\mathrm{I}$ & I & I & $\mathrm{I}$ & $\mathrm{I}$ & $\mathrm{I}$ & I & $\mathrm{I}$ & $\mathrm{I}$ & I & 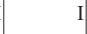 \\
\hline Kısmi Süreli & $-1,10$ & 0,08 & 159,352 & $0,331 * * *$ & $-0,92$ & 0,14 & 41,309 & $0,396^{* * *} \mid$ & $-0,51$ & 0,12 & 18,238 & $0,595 * * *$ \\
\hline $\begin{array}{l}\text { İşyeri Ölçeği işçi sayısına } \\
\text { göre }\end{array}$ & & & 16,713 & **| & & & & & & & 19,076 & *** \\
\hline 1-10 mikro ölçek & $-0,20$ & 0,08 & 5,950 & $0,814 *$ & & & & & $-0,47$ & 0,16 & 8,489 & $0,621 * *$ \\
\hline 11-49 küçük ölçek & $-0,30$ & 0,07 & 15,269 & $0,735 * * *$ & & & & & $-0,66$ & 0,15 & 17,987 & $0,516^{* * *}$ \\
\hline 50-249 orta ölçek & $-0,21$ & 0,07 & 8,362 & $0,805^{* *}$ & & & & & $-0,40$ & 0,15 & 7,296 & $0,668 * *$ \\
\hline 250-499 büyük ölçek & $-0,25$ & 0,10 & 5,801 & $0,776^{*}$ & & & & & $-0,25$ & 0,20 & 1,478 & 0,775 \\
\hline 500 ve üzeri büyük ölçek & I & $\mathrm{I}$ & I & I & $\mathrm{I}$ & $\mathrm{I}$ & $\mathrm{I}$ & $\mathrm{I}$ & $\mathrm{I}$ & $\mathrm{I}$ & I & 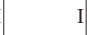 \\
\hline Özel Sektör & 1,62 & 0,09 & 316,569 & $5,060 * * *$ & 1,27 & 0,10 & 136,859 & $3,573^{* * *}$ & 1,47 & 0,16 & 84,161 & $4,370 * * *$ \\
\hline Sendika üyesi & $-0,17$ & 0,07 & 5,432 & $0,840^{*}$ & & & & & $-0,59$ & 0,15 & 14,190 & $0,554 * * *$ \\
\hline Tís kapsamında & 0,37 & 0,07 & 26,079 & $1,451^{* * *}$ & 0,40 & 0,07 & 32,039 & $1,498 * * *$ & & & & \\
\hline Meslekler & & & 49,299 & **** & & & 31,634 & $* * *$ & & & 109,827 & $* * *$ \\
\hline Yönetici ve profesyoneller & 0,41 & 0,11 & 12,865 & $1,506^{* * *}$ & 0,38 & 0,12 & 9,461 & $1,469 * *$ & 1,05 & 0,30 & 12,275 & $2,870^{* * *}$ \\
\hline Tek. ve yard. prof & 0,15 & 0,12 & 1,612 & 1,170 & $-0,00$ & 0,13 & 0,001 & 0,996 & 1,10 & 0,30 & 12,903 & $3,016^{* * * *}$ \\
\hline İd. ve sek. meslekleri & 0,24 & 0,12 & 3,769 & 1,275 & $-0,29$ & 0,19 & 2,265 & 0,743 & 1,54 & 0,28 & 28,782 & $4,690^{* * * *}$ \\
\hline $\begin{array}{l}\text { Ticaret, personel, satış ve } \\
\text { tüketici hizm. }\end{array}$ & $-0,05$ & 0,11 & 0,210 & 0,949 & 0,18 & 0,12 & 2,289 & 1,206 & $-0,34$ & 0,32 & 1,103 & 0,710 \\
\hline Makine operatörleri & 0,47 & 0,12 & 13,631 & $1,605 * * *$ & 0,21 & 0,13 & 2,548 & 1,242 & 1,42 & 0,39 & 13,181 & $4,152 * * *$ \\
\hline
\end{tabular}




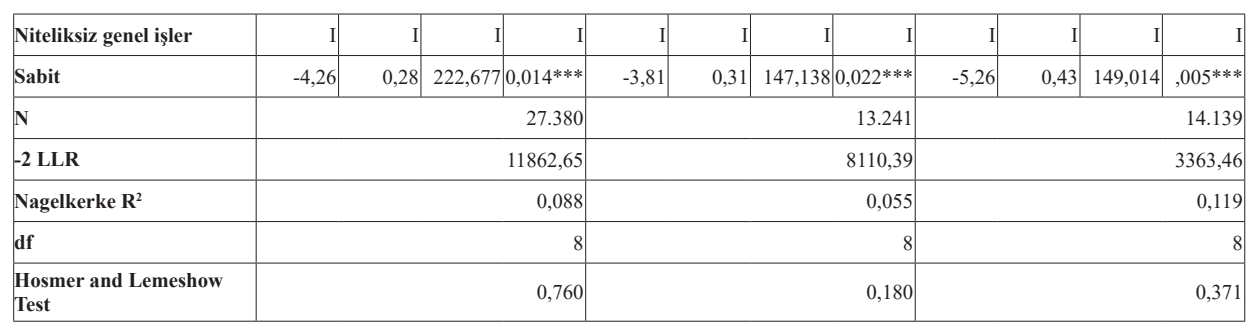

Kaynak: 2014 (Q4/Autumn) İngiliz İşgücü Anketi'nden yazarın kendi analizi Referans kategorisine göre anlamlılık düzeyi: ${ }^{*} \mathrm{p}<, 05 ; * * \mathrm{p}<, 01 ; * * * \mathrm{p}<, 001$.

Eğitim durumuna gelince, modeller eğitim değişkeninin yeşil işlerdeki istihdam olasılığını açıklayan önemli bir değişken olduğunu ve eğitim düzeyindeki artışın lineer olarak yeşil işlerdeki istihdam olasılığını da anlamlı bir biçimde arttırdığını göstermektedir. Örneğin, üniversite ve eşdeğer bir eğitim düzeyine sahip olanların yeşil işlerde çalışma olasılığı, eğitimi olmayanlara göre, tümünde $(\mathrm{OR}=1,688, \mathrm{p}<, 001)$ ve erkekte $(\mathrm{OR}=1,554$, $\mathrm{p}<, 001) 1$ kattan daha fazla iken, kadında $(\mathrm{OR}=2,005, \mathrm{p}<, 05) 2$ kat fazla görülmektedir.

Modellere çalışma şekli yönünden bakıldığında, kısmi süreli işlerde istihdam edilenlerin yeşil işlerde çalışma olasılığı, tümünde $(\mathrm{OR}=0,331, \mathrm{p}<$ ,001), erkekte $(\mathrm{OR}=0,396, \mathrm{p}<, 001)$ ve kadinda $(\mathrm{OR}=0,595, \mathrm{p}<, 001)$, tam süreli işlerde istihdam edilenlere göre, anlamlı şekilde düşük gözlenmektedir.

Tümü ve kadın için oluşturulan modeller, işyeri ölçeği ile yeşil işlerdeki istihdam olasılığı arasındaki ilişkiyi açıklayan önemli bir değişken olmasına rağmen, erkek için oluşturulan model, işyeri ölçeği ile yeşil sektör istihdam olasılığını açıklayan herhangi bir ilişki bulamamıştır. Buna göre, küçük ölçekli işyerlerinde çalışanların yeşil işlerde istihdam edilme olasılı̆̆ 1 , tümünde $(\mathrm{OR}=0,735, \mathrm{p}<, 001)$ ve kadında $(\mathrm{OR}=0,516, \mathrm{p}<, 001)$, büyük ölçekli işyerlerine göre, anlamlı şeklide daha düşük gözükmektedir.

Lojistik modeller, özel sektörün yeşil işlerde çalışma olasıllı̆gnı, kamu sektörüne göre, tümünde (OR=5,060, p< ,001) 5 kattan, erkekte $(\mathrm{OR}=3,573, \mathrm{p}<$,001) 3,5 kattan ve kadında $(\mathrm{OR}=4,370, \mathrm{p}<, 001) 4$ kattan daha fazla yükselttiğini bulmuştur.

Erkek için oluşturulan model, sendika üyeliği ile yeşil işlerde istihdam olasılığını açıklayan herhangi bir ilişki bulamazken, kadın için oluşturulan model, TİS kapsamı ile yeşil işlerde istihdam olasılığını açıklayan herhangi 
bir ilişki bulamamıştır. Buna göre, sendika üyeliği kadınların $(\mathrm{OR}=0,554$, $\mathrm{p}<, 001)$ yeşil işlerde çalışma olasılı̆̆ını anlamlı şekilde düşürüyorken, TİS kapsamı ise, erkeklerin $(\mathrm{OR}=1,498, \mathrm{p}<, 001)$ yeşil sektörlerde istihdam edilme olasılığını anlamlı şekilde artırmaktadır.

Son olarak, mesleklerin de yeşil işlerdeki istihdam olasılığını etkileyen önemli bir değişken olduğu görülmektedir. Modeller incelendiğinde, yöneticilik ve profesyonel mesleklerin, nitelik gerektirmeyen genel işlere kıyasla, yeşil sektörde istihdam olasılığını tümünde $(\mathrm{OR}=1,506, \mathrm{p}<, 001)$, erkekte $(\mathrm{OR}=1,469, \mathrm{p}<, 001)$ ve kadında $(\mathrm{OR}=2,870, \mathrm{p}<, 001)$ anlamlı bir şekilde yükselttiği görülmektedir. Ayrıca, yeşil sektörlerdeki idari ve sekreterlik meslekleri $(\mathrm{OR}=4,490, \mathrm{p}<, 001)$ ile süreç, tesis ve makine operatörlügüu $(\mathrm{OR}=4,152, \mathrm{p}<, 001)$ mesleklerinin kadınların istihdam edilme olasılığını, nitelik gerektirmeyen genel işlere göre, 4 kattan daha fazla artırdığı gözlenmektedir.

\section{Sonuç}

Bu çalışmada, yeşil ekonominin istihdama yansımaları ve yeşil işlerle ilgili ampirik çalışmalara katkı sağlamak amaciyla, demografik profil ve istihdam durumu değişkenlerinin yeşil işlerle ilişkisindeki cinsiyet farklılıklarının doğası, İngiltere örneği üzerinden ki-kare analizi ve iki yönlü lojistik regresyon modellemeler kullanılarak araştırılmıştır. Elde edilen sonuçlara göre, İngiltere'deki yeşil işlerin demografik profil ve istihdam durumu değişkenleri ile anlamlı bir şekilde ilişkili olduğu ve yeşil sektörlerin kadınlar aleyhine istihdamda bir cinsiyet eşitsizliği yarattığı görülmüştür. Bu sonuç, Bird ve Lawton'un (2009) İngiltere'de yeşil sektörlerde kadın istihdamının erkeklerden daha az olduğunu bildiren araştırma bulgularını da teyit etmektedir.

Çalışmanın orijinal bulgularına bakacak olursak, modeller yeşil işler ile yaş bantları arasında doğru orantılı bir ilişki tespit etmiştir. Yani, yaş arttıkça, yeşil işlerdeki istihdam olasılığı da artmaktadır. Bu sonuç, İngiltere'deki yeşil sektörlerin genç istihdamı bakımından iyi olanaklar sunmadığına işaret etmektedir. Diğer taraftan, lojistik analiz Galler'deki yeşil iş olanaklarının, diğer ülkelere göre, daha fazla olduğu sonucuna ulaşmıştır.

Analiz sonuçlarımız İngiltere'de eğitim durumu ile yeşil işler arasında da doğru orantılı bir ilişki tespit etmiştir. Yani, eğitim düzeyi yükseldikçe, yeşil işlerde istihdam olasılığı da yükselmektedir. Bu sonuç, İngiltere'deki 
yeşil sektörlerin daha çok üniversite ve eşdeğer eğitim düzeyindekilerin niteliklerine uygun işler sunduğunu ve bu eğitim düzeylerine sahip olmanın, yeşil işlerdeki cinsiyet eşitsizliğini azalttığını açıkça göstermektedir. $\mathrm{Bu}$ bulgu, Almanya ve İspanya'da yenilenebilir enerji sektöründe istihdam edilenler içerisinde üniversite derecesi ve mesleki eğitim düzeyine sahip olanların oranının, ortalama ulusal işgücünden daha yüksek olduğunu ileri süren araştırma sonuçlarını da desteklemektedir (ILO, 2013b, s.33-34).

Lojistik modeller İngiltere' de yeşil işlerde kısmi süreli çalışma olanaklarının oldukça sınırlı olduğunu göstermektedir. Bu sonuç, Almanya ve İspanya'daki yenilenebilir enerji sektörlerindeki yeşil işlerin önemli bir bölümünün tam zamanlı ve daimi işlerden oluştuğunu bildiren araştırma bulgularıyla da örtüşmektedir (ILO, 2013b, s.33-34). Diğer taraftan analiz sonuçları, kadınların kısmi süreli yeşil işlerde çalışma olasılıklarının erkeklerden daha yüksek olduğunu bulmuştur. Bird ve Lawton'un (2009) çalışmalarını da teyit eden bu sonuç, bu çalışmadan elde edilen yeşil işlerde kısmi süreli çalışma imkânlarının düşük olduğu sonucuyla birleştirildiğinde, İngiltere'de kadınlara uygun alternatif çalışma imkanı sunmayan yeşil endüstrilerin aslında kadınlar aleyhine istihdamda cinsiyet eşitsizliğini artırdığı söylenebilir.

Lojistik analiz sonuçlarına göre, İngiltere'deki küçük ölçekli işyerleri yeşil iş olanaklarını düşürüyorken, özel sektör, kamu sektörüne göre, daha fazla yeşil iş sunmaktadır. Diğer taraftan, esnek çalışmaya daha açık olan özel sektördeki yeşil endüstriler, kamu sektöründekilere göre, istihdamdaki cinsiyet eşitsizliğini daha fazla azaltmaktadır.

Lojistik modeller, yeşil işlerde çalışan sendikalı ve sendikasız erkekler arasında anlamlı bir farklılık bulamamasına rağmen, TİS kapsamının erkeklerin yeşil işlerdeki istihdam olasılığını artırdığını bulmuştur. Bu sonuç, özellikle yeşil yakalı erkek çalışanların genellikle direkt bir sendikaya üye olmaktan ziyade, dayanışma aidatı ödeyerek, TİS kapsamına girmeyi tercih ettiklerini düşündürmektedir.

Son olarak, eğitim durumu sonuçlarının bir yansıması olarak, lojistik analiz yöneticilik ve profesyonel meslekler gibi yüksek mevkili mesleklerin ve süreç tesis ve makine operatörlüğü gibi orta düzey vasıf gerektiren mesleklerin, yeşil işlerdeki istihdam olasılığını artırdığına işaret etmektedir. Bu sonuç, Bird ve Lawton'un (2009) İngiltere' de yeşil sektörlerde ticari ve finansal hizmetler 
ile elektrik üretimi hizmetlerindeki yeşil işlerde çalışanların çoğunluğunun daha yüksek vasıflara sahip olduğunu ileri süren araştırma sonuçlarını da desteklemektedir. Ayrıca bu sonuçlar, yeşil sektörlerde iş bulma konusunda jenerik becerilere sahip yüksek vasıflı işçilerin, düşük vasıflı işçilere göre, daha fazla şanslarının olduğunu ileri süren araştırma bulgularıyla da benzerlik göstermektedir (European Commission, 2012, s.10).

Yukarıda detaylı bir şekilde anlatıldığı gibi, yeşil ekonomik yapılanmanın işgücü üzerindeki negatif sonuçlarını azaltmak ve genel ekonomide daha fazla ve daha düzgün işler yaratmak için yeşil ekonomiye geçiş sürecinde işletme, toplum ve ulusal seviyesinde pro-aktif bir yaklaşımla yürütülen bir takım politikaları gerekli k1lmaktadır (Strietska-Ilina, 2011, s.56). Bu açıdan, yeşil ekonomiye geçişte sosyal diyalogla işletilen istihdam ve beceri geliştirme politikaları son derece önemlidir (ILO ve OECD, 2012, s.2). Bu çerçevede, ILO ve OECD tarafindan da önemli bulunan bir takım politika önerileri kısaca şöyle özetlenebilir:

- İlk olarak, yeşil girişimciliğin önündeki engellerin kaldırılması yeşil işlerin sayısının artırılması bakımından son derece kritiktir. Bu açıdan, genel olarak daimi istihdamın 2/3'ünden fazlasını yaratan KOBİ'ler kilit bir role sahiptir. Bu nedenle, yeşil sektörlerde faaliyet gösteren KOBİ'lerin bilgiye, finansal kaynaklara ve nitelikli işgücüne erişimini kolaylaştıran politikalar desteklenmelidir.

- Yeşil sektörlerin uygun iklim ve yatırım koşullarına sahip bazı bölgelerde büyümesi oldukça muhtemeldir. Bu yüzden, daha az yatırım alan bölgeler de kamu teşvikleri ile özel sektör yatırımlarına uygun hale getirilmelidir (Jacobs, 1991, s.180).

- Yeşil ekonomiye geçiş sürecinde endüstri içinde ve endüstriler arasında yaşanacak muhtemel istihdam kaymalarına karşı ihtiyaç duyulacak işvasıf gerekliliklerini karşılamaya hazır olmak için gerekli aktif istihdam politikaları oluşturulmalıdır. Bu anlamda, çalışanlara iletişim, stratejik planlama, liderlik ve yönetim temel beceri setlerinin yanı sıra, bazı özel beceri ve yetkinliklerin kazandırılması gerekebilir (European Commission, 2012, s.9-10).

- Yeşil ekonomiye geçiş, işçiler ve aileleri için yeni fursatlar ve riskleri beraberinde getirdiği için yeterli pasif istihdam politikaları ile kaçınılmaz 
maliyetler en aza indirgenmeli ve eşit bir şekilde paylaşılmalıdır. Böylece işçiler ve aileleri için yeşil ekonomiye adil bir geçiş güvence altına alınmalidir.

- Gelişen yeşil sektörlerde çalışanları ve ailelerini yoksulluktan kurtaracak kadar yeterli gelir sunan düzgün işlerin teşvik edilmesinin yanı sıra, çalışan haklarının uluslararası çalışma hakları düzeyine çıkarılması, adil bir geçişin sağlanması bakımından önemli bir başarı noktasıdır.

- Yeşil ekonomideki cinsiyet eşitsizliğini azaltmak için, toplumsal cinsiyete duyarlı yönetişim, tutum, davranış ve uygulamalara yönelik yasal altyapılar oluşturulmalıdır. Ayrıca, kadınların yeşil iş olanaklarına ulaşmalarını ve bu alanda eğitim almalarını zorlaştıran her türlü sosyal ve ekonomik engele karşı tüm toplum kesimleri önce bilinçlendirilmeli, sonra işbirliği içinde birlikte mücadele etmelidir (ILO, 2015, s.8).

- Son olarak, yeşil işlerdeki kadın istihdamının artırmaya dönük, kadın istihdamını kolaylaştıran esnek çalışma modelleri teşvik edilmelidir.

$\mathrm{Bu}$ çalışma kapsamında, yeşil ekonominin istihdama yansımaları ve yeşil iş göstergeleri üzerine odaklanılmış olup, yeşil ekonomiye geçiş sürecinde uygulanacak istihdam politikaları kısaca özetlenmiştir. Bu açıdan, gelecek çalışmaların yeşil ekonomiye adil bir geçiş sağlayacak ve cinsiyet eşitsizliklerini azaltacak istihdam politikalarına yoğunlaşması, bu alandaki literatür ve bilgi birikiminin artmasına önemli katkılar sağlayacaktır.

Finansal Destek: Yazar bu çalışma için finansal destek almamıştır. 


\section{Kaynakça/References}

Baykan, B. G. (2009). Dünyada ve Türkiye'de Yeşil Yakalılar. Betam Araştırma Notu, 09/37. İstanbul, 1-4.

Bird, J., \& Lawton, K. (2009). The Future's Green: Jobs and the UK Low-carbon Transition. Institute for Public Policy Research (IPPR) Challenging Ideas- Changing Policy.

British Department for Business Innovation \& Skills (BIS) (2013). Low Carbon and Environmental Goods and Services, Report 2011-12, UK London.

British Department for Energy and Climate Change (DECC) (2009). The UK Low Carbon Transition Plan: National Strategy for Climate and Energy. White Paper, UK London.

Bowen, A. (2012). 'Green' Growth, 'Green'Jobs and Labour Markets. Centre for Climate Change Economics and Policy Working Paper No. 88, Grantham Research Institute on Climate Change and the Environment, Working Paper No. 76.

CBI (2012). The Colour of Growth: Maximising the Potential of Green Business. London: The Confederation of British Industry Report, 1-33.

EMCO (2010). Towards a Greener Labour Market-The Employment Dimension of Tackling Environmental Challenges. EMCO Reports, ISSUE 4.

Erden Özsoy, C. (2016). Yeşil İşler ve İstihdam Olanakları Üzerine Bir Tartışma. Aksaray Üniversitesi İktisadi ve İdari Bilimler Fakültesi Dergisi, 8(1), 51-59.

European Commission (2012). Exploiting the Employment Potential of Green Growth. Strasbourg: Commission Staff Working Document, SWD (2012) 92 Final, 1-16.

Evans-Klock, C., Poschen, P., Sanchez, A. B., \& Hofmann, C. (2009). ILO Green Jobs Initiative and Implications for Skills Development. Future Skill Needs for the Green Economy, Research Paper, Luxembourg: Publications Office of the European Union, 7-17.

Gaušas, S. with assistance from Caturianas, D. Jonušauskaitė, G., Mackonyte, G., Muravjova, O., Nakrošis, V., Paliokaitė, A., Repečkaitė, D., Pocius, D., Stančiauskas V. and Šarūnas, T. (2012). Greening of industries in the EU: Anticipating and Managing the Effects on Quantity and Quality of Jobs. Dublin, Ireland: European Foundation for the Improvement of Living and Working Conditions.

Gordon, K. \& Jeremy, H. (Lead Authors) (2008). Green-Collar Jobs in America's Cities Building Pathways Out of Poverty and Careers in The Clean Energy Economy. Apollo Alliance and Green for All.

Görmüş A. (2016). Yeşil Ekonomiye Geçiş Düzgün İşler İçin Yeni Fırsatlar Yaratıyor Mu? İngiltere Örneği. Atatürk Üniversitesi İktisadi ve İdari Bilimler Dergisi, 30(5), 1081-1093.

Hosmer, D. W., \& Lemeshow, S. (2000). Applied Logistic Regression. 2nd Edition, New York: John Wiley \& Sons, Inc.

ILO (2012). Green Jobs Becoming a Reality Progress and Outlook 2012. Geneva.

ILO (2013a). Green Jobs Becoming a Reality Progress and Outlook 2013. Geneva. 
ILO (2013b). Sustainable Development, Decent Work and Green Jobs. International Labour Conference. Fifth Item on the Agenda, 102nd Session, Geneva: Report V.

ILO (2015). Gender Equality and Green Jobs. Green Jobs Programme Policy Brief.

ILO and OECD (2012). Sustainable Development, Green Growth and Quality Employment. Guadalajara: Meeting of G20 Labour and Employment Ministers, 1-13.

Jacobs, M. (1991). The Green Economy: Environment, Sustainable Development and the Politics of the Future. London: Pluto Press.

Martinez-Fernandez, C., Hinojosa, C., \& Miranda, G. (2010). Green Jobs and Skills: The Local Labour Market Implications of Addressing Climate Change. Working Document, CFE/LEED, OECD.

Metcalf, G. E. (2007). A Green Employment Tax Swap: Using A Carbon Tax To Finance Payroll Tax Relief. Tax Reform, Energy and the Environment Policy Briefs. World Research Institute, 1-8.

OECD (2011). Towards Green Growth. OECD Ministerial Council Meeting on 25-26 May 2011 Chair's Summary.

OECD (2012). The Jobs Potential of A Shift Towards a Low-Carbon Economy. Final Report For The European Commission, DG Employment.

ONS (2014). Labour Force Survey. Autumn Quarter.

Özsoy, C. (2011). Yeşil ekonominin dinamikleri: Yeşil işler ve beceriler. Finans Politik \& Ekonomik Yorumlar, 48(562), 19-32.

Pollin, R., Heintz, J., \& Garrett-Peltier, H. (2009). The Economic Benefits of Investing in Clean Energy. PERI and the Centre for American Progress.

Schumpeter, J. A. (1942). The Process of Creative Destruction. In Capitalism, Socialism and Democracy, Ch. 7, New York: Harper, 82-85.

Sector: Low Carbon Goods and Services (2014). Skills Action Plan in the D2N2 Area.

Stevens, C. (2009). Green Jobs and Women Workers: Employment, Equity, Equality. Report prepared by Candice Stevens for the International Labour Foundation for Sustainable Development (SustainLabour), ITUC (International Trade Union Confederation).

Stevens, C. (2012). Gender in the Green Economy. News \& Views. United Nations Research Institute for Social Development (UNRISD).

Strietska-Ilina, O., Hofmann, C., Durán Haro, M. and Jeon, S. (2011). Skills For Green Jobs A Global View. Geneva: Synthesis Report Based on 21 Country Studies, ILO.

Sungur, Z. (2011). Green Jobs: Perspective from HRD in Turkey. The 12th International Conference on HRD Research and Practice Across Europe. 25-27 May 2011, Gloucestershire University, UK, 1-14.

UNEP (2011). Towards a Green Economy: Pathways to Sustainable Development and Poverty Eradication - A Synthesis for Policy Makers. Nairobi.

UNEP/ILO/ITUC (2008). Green Jobs: Towards Decent Work in a Sustainable, LowCarbon World Report. Worldwatch Institute Washington DC. 
Upadhyay, H. and Pahuja, N. (2010). Low-Carbon Employment Potential in India: A Climate of Opportunities. Centre for Global Climate Research TERI and Global Climate Framework Discussion Paper. New Delhi: TERI/GCN - 2010:1.

World Bank (2012). Inclusive Green Growth the Pathway to Sustainable Development. Washington DC. 


\section{EK}

\section{Yeşil Ekonomik Aktiviteler-İngiltere Standart Endüstri Sınıflandırması SIC 07 Codes}

\begin{tabular}{|c|c|}
\hline Main Industries & \\
\hline $\begin{array}{l}\text { Manufacture of Electrical } \\
\text { Equipment }\end{array}$ & $\begin{array}{l}\text { 2711: Manufacture of electric motors, generators and transformers } \\
\text { 2712: Manufacture of electricity distribution and control apparatus } \\
\text { 2732: Manufacture of other electronic and electric wires and cables } \\
\text { 2733: Manufacture of wiring devices } \\
\text { 2740: Manufacture of electric lighting equipment } \\
\text { 2751: Manufacture of electric domestic appliances } \\
\text { 2752: Manufacture of non-electric domestic appliances } \\
\text { 2790: Manufacture of other electrical equipment }\end{array}$ \\
\hline $\begin{array}{l}\text { Manufacture of Metal Products } \\
\text { and Equipment }\end{array}$ & $\begin{array}{l}\text { 2521: Manufacture of central heating radiators and boilers } \\
\text { 2530: Manufacture of steam generators, except central heating hot water boilers } \\
\text { 2811: Manufacture of engines and turbines, except aircraft, vehicle and cycle } \\
\text { engines } \\
\text { 2812: Manufacture of fluid power equipment* } \\
\text { 2813: Manufacture of other pumps and compressors } \\
\text { 2821: Manufacture of ovens, furnaces and furnace burners } \\
\text { 2825: Manufacture of non-domestic cooling and ventilation equipment }\end{array}$ \\
\hline Alternative Fuel Vehicles & $\begin{array}{l}\text { 2910: Manufacture of motor vehicles } \\
\text { 3020: Manufacture of railway locomotives and rolling stock } \\
\text { 3099: Manufacture of transport equipment n.e.c. }\end{array}$ \\
\hline $\begin{array}{l}\text { Production and Distribution of } \\
\text { Electricity }\end{array}$ & $\begin{array}{l}\text { 3511: Production of electricity* } \\
\text { 3513: Distribution of electricity * }\end{array}$ \\
\hline $\begin{array}{l}\text { Production and Distribution } \\
\text { of Gas }\end{array}$ & $\begin{array}{l}\text { 3521: Manufacture of gas* } \\
\text { 3522: Distribution of gaseous fuels through mains* } \\
\text { 3530: Steam and air conditioning supply* }\end{array}$ \\
\hline Water Collec., Treat. and Supply & 3600: Water Collection, Treatment and Supply* \\
\hline Sewerage & 3700: Sewerage* \\
\hline $\begin{array}{l}\text { Waste Management and } \\
\text { Remediation Activities }\end{array}$ & $\begin{array}{l}\text { 3811: Collection of non-hazardous waste* } \\
\text { 3812: Collection of hazardous waste* } \\
\text { 3821: Treatment and disposal of non-hazardous waste* } \\
\text { 3822: Treatment and disposal of hazardous waste* } \\
\text { 3831: Dismantling of wrecks* } \\
\text { 3832: Recovery of sorted materials* } \\
\text { 3900: Remediation activities and other waste management services* }\end{array}$ \\
\hline $\begin{array}{l}\text { Green Buildings, } \\
\text { Power and Energy Infrastructure }\end{array}$ & $\begin{array}{l}\text { 4110: Development of building projects } \\
\text { 4120: Construction of residential and non-residential buildings } \\
\text { 4221: Construction of utility projects } \\
\text { 4299: Construction of other civil engineering projects n.e.c. } \\
\text { 4329: Other construction installation* } \\
\text { 4399: Other specialised construction activities n.e.c.* }\end{array}$ \\
\hline $\begin{array}{l}\text { Environmental Engineering and } \\
\text { Technical Consultancy }\end{array}$ & $\begin{array}{l}\text { 7111: Architectural activities } \\
\text { 7112: Engineering activities and related technical consultancy }\end{array}$ \\
\hline Environmental R\&D & $\begin{array}{l}\text { 7211: Research and experimental development on biotechnology* } \\
\text { 7219: Other research and experimental development on natural sciences and } \\
\text { engineering* } \\
\text { 7490: Other professional, scientific and technical activities n.e.c*. }\end{array}$ \\
\hline $\begin{array}{l}\text { Specialised Cleaning and } \\
\text { Landscape Service Activities }\end{array}$ & $\begin{array}{l}\text { 8122: Specialised cleaning services* } \\
\text { 8130: Landscape service activities* }\end{array}$ \\
\hline
\end{tabular}

Kaynak: Sector: Low Carbon Goods and Services, (2014), Skills Action Plan in the D2N2 Area, s.24

*2014 (Q4/Autumn) İngiliz İşgücü Anketi’nden yazar tarafından eklenmiştir. 